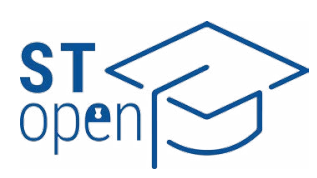

(c) 2021 The Author(s)

ST-OPEN @ 202

\title{
Transformation of the city of Split industrial heritage into a science center
}

\author{
Sandro Žuljević (1)
}

Faculty of Civil Engineering, Architecture and Geodesy, University of Split, Split, Croatia
Correspondence to:

Sandro Žuljević

University of Split, Faculty of Civil Engineering, Architecture and Geodesy, 21000 Split, Croatia sandrozulj@gmail.com

Cite as:

Žuljević S. Transformation of the city of Split industrial heritage into a science center. STOPEN. 2021; 2: e2021.1903.4.

DOI:

https://doi.org/10.48188/so.2.10
Background: Split is a city in the Mediterranean, situated on Croatia's coastline. Split's northern coast has a long-standing industrial function and harbors the city's first electrical substation, designed by modernist architect Josip Maria Kodl.

Objective: The goal of this work was to envision a science center in Split's industrial zone in Dujmovača (the northern coast of the Split peninsula), comprising a science museum with a research and congress center. The programmatic and spatial analyses of the science center's amenities and the proposal as a whole demonstrate the potential of this forgotten space in Split and breathe new life into Kodl's architectural heritage.

Methods: The proposed solution uses a dialogical narrative between a conservation, contextual, programmatic, and theoretical approach within a strict orthogonal structure, fostering the development of alternative associations and elaboration of architectural details.

Results: The proposed solution constitutes a complex of multiple interconnected and flexible elements. This allows different parts of the Science Center to function independently of each other. This paper provides an analysis of design steps and methods, the proposal's advantages and limitations, and the way the repurposing of industrial heritage was approached.

Conclusion: The position of the Science Center in Dujmovača would provide one of the first impressions when entering Split on the future metro line. By reconciling landscape and industrial architecture, the proposed building complex offers a framework for presenting various kinds of modifiable content, for both the present and the future. 


\section{Introduction}

The revitalization of industrial heritage is synonymous with the term "industrial archaeology" and refers to the on-site preservation, adaptive reuse and repurposing of existing industrial buildings (Palmer, 2008). Since the mid-1980s, many such projects have been undertaken in Europe. The European Route of Industrial Heritage (ERIH) is a potent example of how initiatives for the revitalization of industrial heritage have been successful in recent years.

In this study, a solution will be presented of how an industrial heritage site in the city of Split, Croatia, could be revitalized, as well as how new functions and amenities could be implemented on the site. Understanding the purpose of this project and the location choice first requires an explanation of the complex geographic, urban, and historical image of the city, since the project is based on the intertwining of history, architecture, and the current urban situation. Along with this, it is necessary to understand the ways in which industrial heritage can be reused and revitalized so that the proposed architectural creation can be placed into a theoretical context.

Split, the second largest city in Croatia, is an example of a Mediterranean city that bases its brand and most of its economy on tourism (see Figure 1). Thus, the impact of tourism on the city can also be seen in its urban development. The thin line between the actual life of the city and the life devised for and presented to "those looking from the outside" is becoming more and more indistinguishable even to the locals, who are increasingly

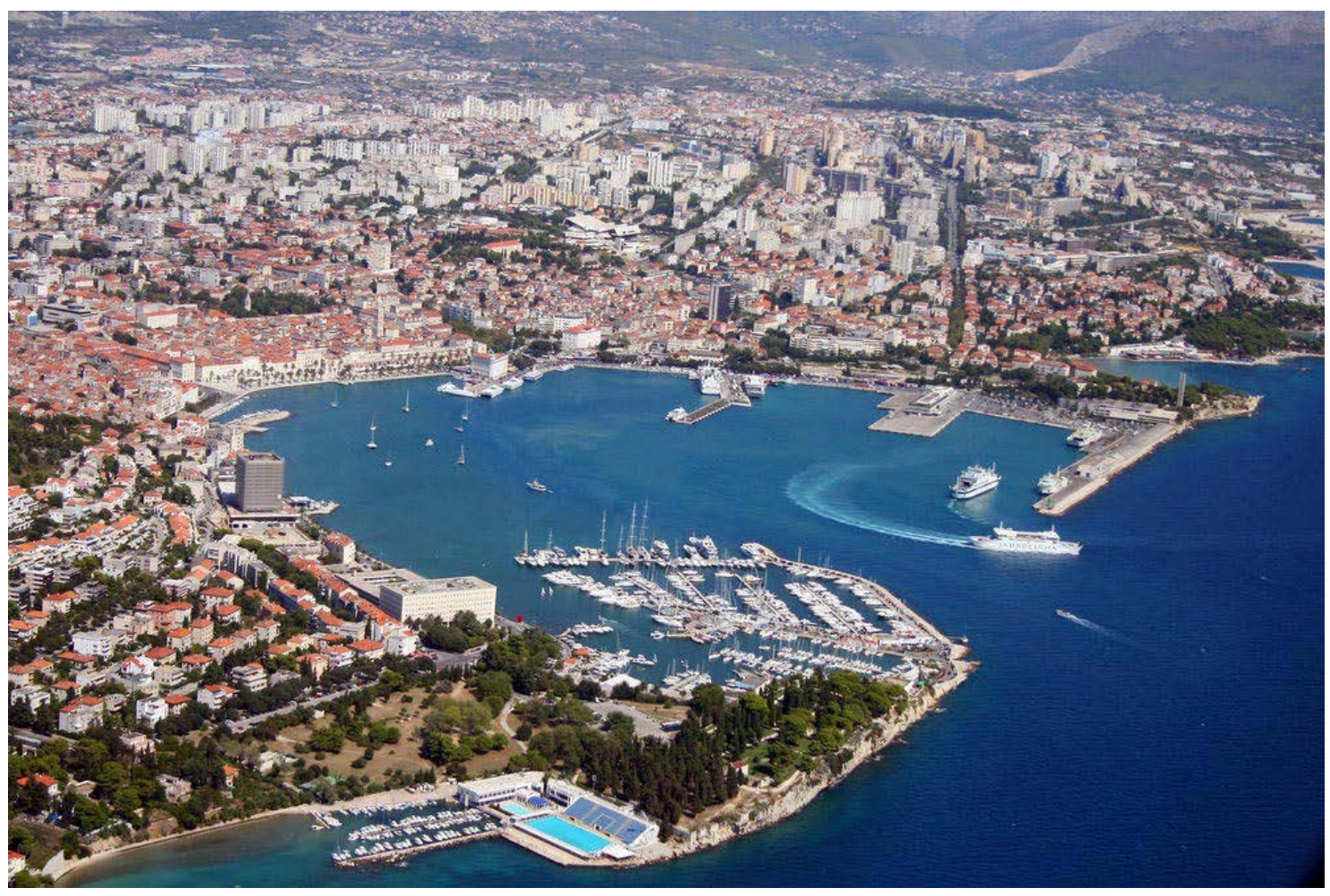

Figure 1. A typical view of the south-west part of the city of Split, and the city's port open to the Adriatic Sea. However, Split is situated on a peninsula and also has a North Bay, officially called the Kaštela Bay (see Figures 2 and 3). Reproduced with permission from the University of Split, Split, Croatia. 
adapting their living spaces to the concept of Split as a tourist destination (Pavičić, 2016). This situation requires creative solutions, a continuous re-evaluation of the city's urban planning and constant adaptation to new situations. The merging of Split's industrial history with the industry of the future represented by information technology (IT) is an example of the reconciliation between the two concepts, which can lead to reestablishing the authenticity of the city and present an opportunity for city development and profiling.

The proposed architectural solution develops the idea of establishing a science center on the northern coast of the city (Figure 2), which already exists as an idea conceived by the late Split architect Vjekoslav Ivanišević and HEP's (the main Croatian electric power company) director Božidar Budanko in 1993. Ivanišević revived this idea in 2010 and created an initiative committee for the establishment of the Science Museum in Split (Arhitektonska radionica centar d.o.o., 2015; Ivanišević, 2010). The project was a part of Ivaniševićs mayoral election campaign in 2013 (Croatian Democratic Union, 2013); in 2015, it became one of the strategic projects of Split's candidacy for the European Capital of Culture 2020 (City of Split, 2015b).

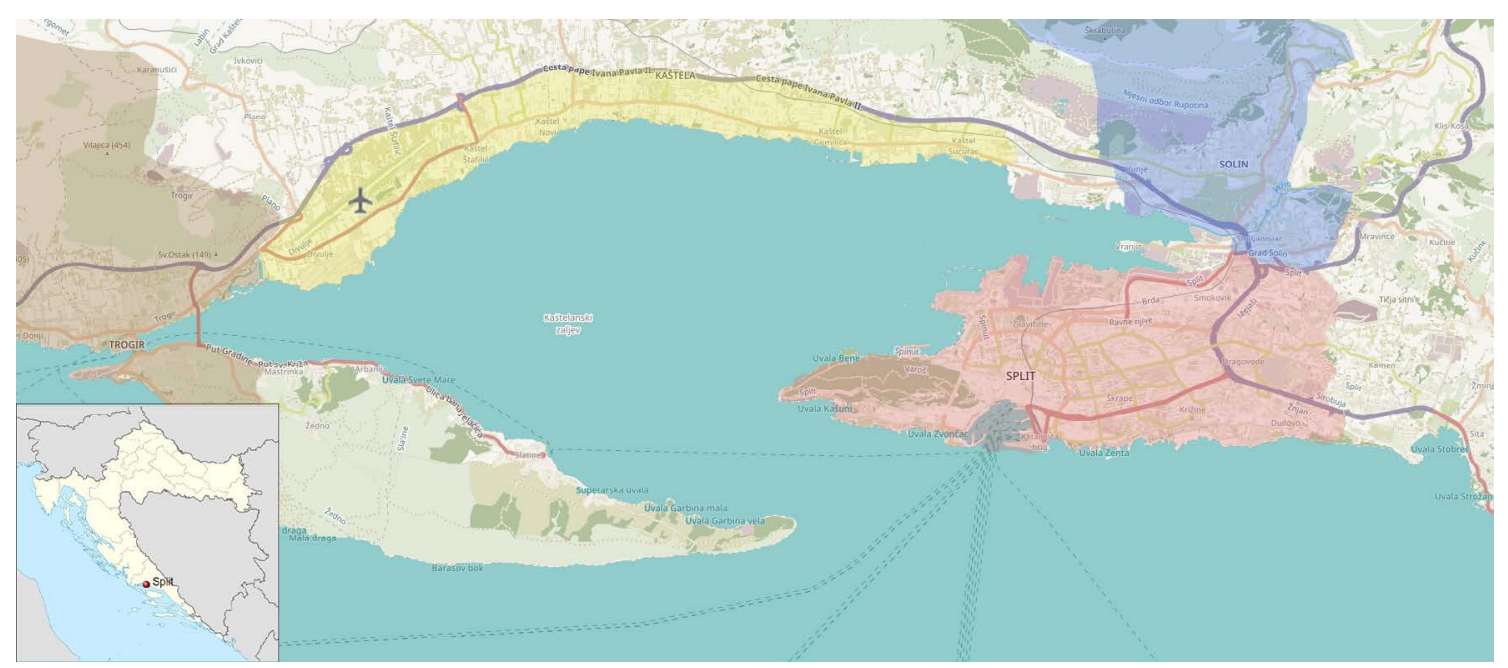

Figure 2. Blueprint of the city of Split (red color), with the town of Solin (blue), Kaštela Bay (yellow), and with the town of Trogir (brown). The name of the bay is related to the city of Kaštela on the north coast of the bay. The town of Solin developed on the location of the ancient city of Salona which was the capital of the Roman province of Dalmatia and the birthplace of the emperor Diocletian. The site of the project presented in this work is marked with a red dot. See also Figure 3. Source: “৫ OpenStreetMap contributors”.

The initiative then morphed into an architectural project with a new amenities program as a part of as a part of the author's master's thesis during his architecture studies at the Faculty of Civil Engineering, Architecture and Geodesy in Split. This article is a continuation of the synthetic research confirming the potential of this location as one of the focal points of the wider new urban area of Split. The Science Center is presented as a stimulus and reconciliation between the development of tourism and the development of the city's industry. The northern coast of Split is an industrial zone and a very attractive area for the development of city tourism. The project may, therefore, provide "added value" by transforming this space into an opportunity for tourism development, without neglecting other business sectors in the area. In accordance with Budanko's and Ivaniševićs idea of transforming the protected electrical substation complex in Dujmovača into a Science Museum, Dujmovača was selected as the location for the intervention. 


\section{The city's historical development and urban planning}

The city of Split, located on the east coast of the Adriatic Sea, became a part of the newly formed Kingdom of Yugoslavia in 1918 at the end of World War I, and thus its most important sea port. Consequently, it underwent a period of intense construction and development, which resulted in a greater need for urban planning. A new commercial port was initially devised in the western part of the city port based on a city plan created by engineer Petar Senjanović in 1914. The regulatory plan of Split, based on the 1924 work of architect Werner Schurmann, placed the new port in the bay of Poljud. Despite these plans, economic reasons drew a decision in 1938 to build a commercial port in the bay of Vranjic. Since the city sits on a peninsula, its southern part was then designated as a residential and tourist area. The northern coastal belt was designed as a service and industrial zone (Figure 3) (Duplančić, 2004).

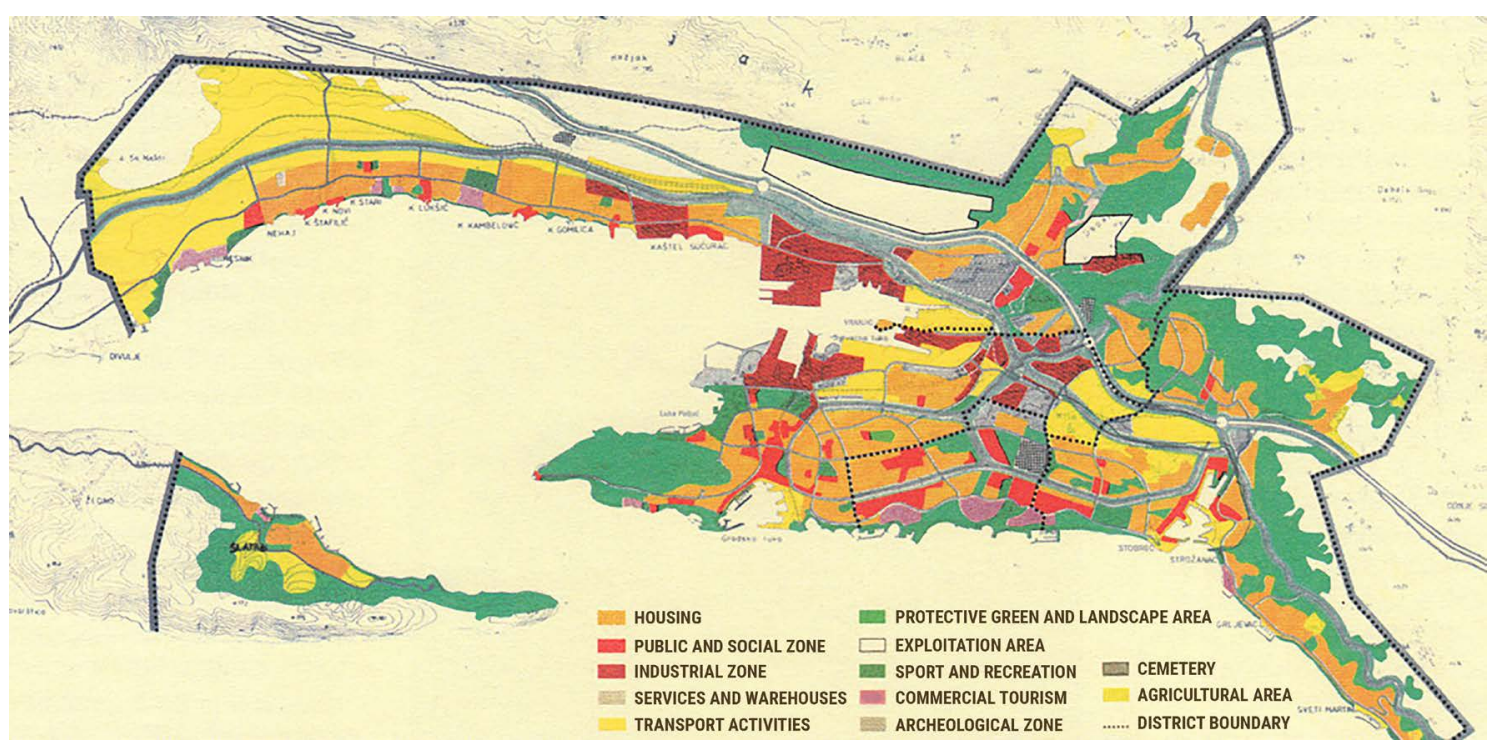

Figure 3. General urban plan of Split from 1978. The areas intended for industry and manufacturing trades are marked in dark red, the areas intended for housing in orange, and those intended for transport activities in yellow. Designer: City Planning Institute for Dalmatia. Source: Institut IGH d.d., 2011.

After World War II, in the Socialist Federal Republic of Yugoslavia, a new trading port was gradually constructed in the northeastern part of the Split peninsula, which further emphasized the general service and industrial purpose of the northern coast. This layout precluded the possibility of connecting the northern coastal belt with the neighboring Kaštela Riviera, thus limiting any further urban development. The city continued to expand to the east (Figure 3) (Duplančić, 2004). For future guidelines for the city's development, it is important to be aware of the mechanisms that led to the definition of this coastal zone of the city. Due to this functional polarization of the Split peninsula, as well as the demands of the city's development, the northern coast still retains its purpose today. The industrial architectural heritage has thus left its mark on current and future urban solutions.

The concentration of industry and tertiary activities in Split resulted in a greater need for new workers. The new workforce mostly came from rural settlements from the city's hinterland, resulting in a sudden housing crisis due to increased demand. Since 1958, several socially oriented collective building programs have emerged, but they failed to find a 
satisfactory solution to the fast city growth. Uncontrolled housing construction resulted in different settlements on the outskirts of the city, including the city districts of Brda, Kman, Visoka, and Neslanovac. Today, a number of negative features related to the development of an industrial city are present in Split, such as an uncontrolled spatial expansion of the city, spatial social segregation based on origin and income, and housing deprivation (Klempić, 2004).

\section{Dujmovača}

Discussions on the architectural and cultural heritage of Split mostly deal with the city's historic center and its historic styles from the Roman period to Art Nouveau, whereas the initiatives aimed at promoting modern architectural heritage, and especially industrial achievements, have only recently emerged. An example of such buildings is the electrical substation complex in Dujmovača, which is also the area of intervention for this project (Figure 4). Its location is protected by high cypresses between the route of the old Split Solin road and the railway. The substations were built in 1926 and were designed by Josip Kodl, the first modern architect in Split (Plejić, 2003).

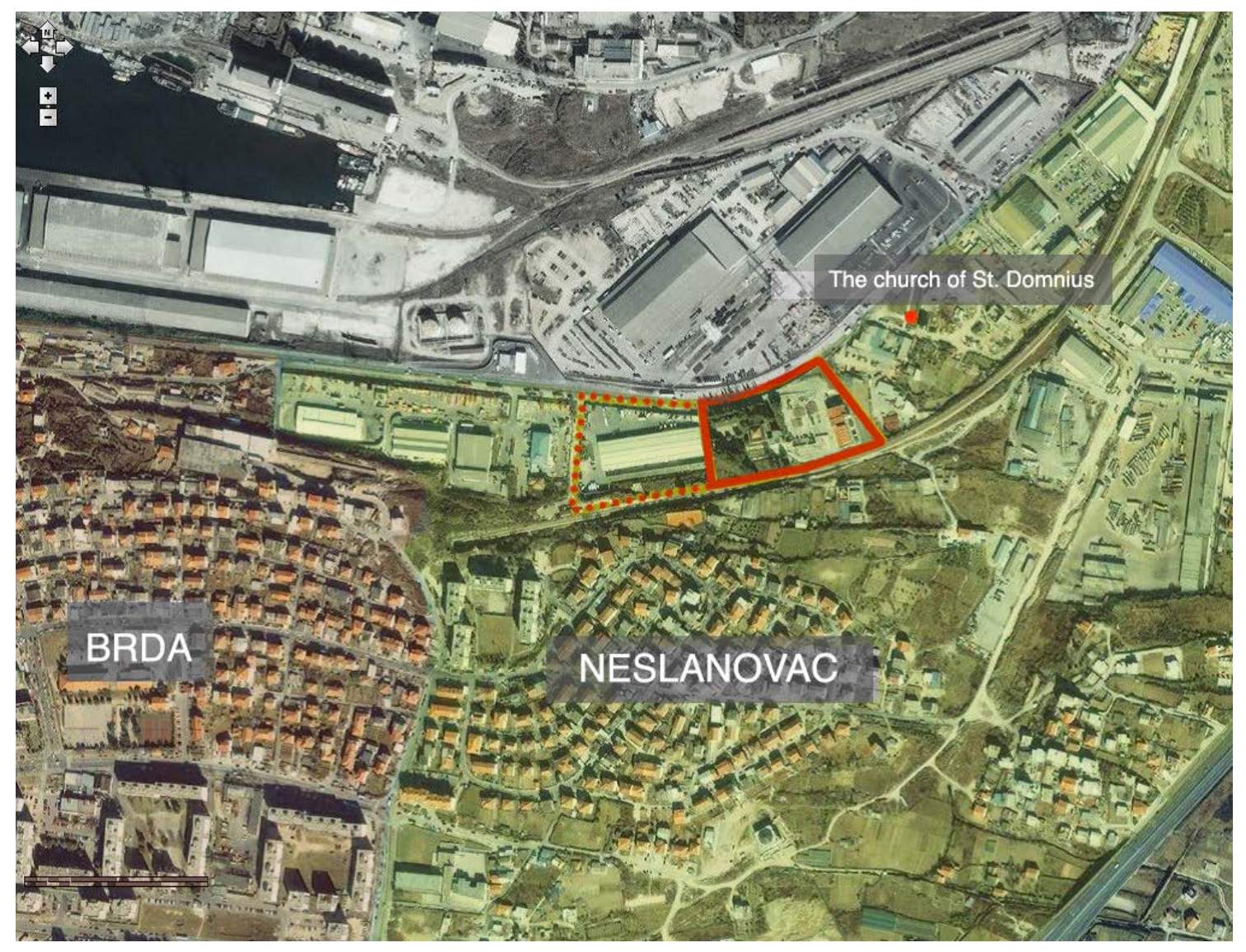

Figure 4. A depiction of the location in Dujmovača (solid red line) and its possible expansion (dotted red line). The church of St. Domnius is located nearby (marked by the red dot). The names of the city's residential neighborhoods are indicated in white. Source: Google Earth. 
Today, Dujmovača is a somewhat deteriorated area, and its atmosphere is an unusual combination of industrial and park architecture featuring a host of brick details. The brick and cement industry was the first industry to develop there, in 1875 (Žižić, 2015). Next to the area where Kodl's substations are located, there is a small church dedicated to St. Domnius, dating from 1747. This location is mentioned in different sources as the place where, in the 7th century, the people of Split decided to rest and recuperate when carrying the bones of St. Domnius, the patron saint of the City of Split, a Bishop from Salona around the year 300 (Muljačić, 2005) (Appendix 1).

\section{Architecture by Josip Maria Kodl}

Josip Maria Kodl, the designer of the electrical substations in Split, was a Czech modernist architect who realized his professional career in Split (Figure 5). He was born in 1887 in Zdice, Czech Republic. He graduated from the Czech College in Prague in 1921 and came to Split as a young architect, at the urging of his colleagues Fabijan Kaliterna, Lovro Krstulović, and others, with whom he had been friends since his student days. He found a new homeland in Split, became a citizen of Yugoslavia, and took a job working for the Technical Construction Department of the Split Municipality, namely in the Building Construction Section (Piplović, 1987; Piplović \& Franić, 2003).

As a radical supporter of functionalist architecture, he advocated the principle of introducing new contemporary styles into historical environments and built some of the first modern buildings, such as the meteorological observatory on the Marjan peninsula (the first flat roof in Split, 1925), the Manuš-Dobri Elementary School (1930), the Kodl Villa in 1 Glagoljaška ulica (1927), the Ambasador Hotel (built in 1937 and torn down in 2017), and the "Gusar" Rowing Club on Matejuška (built in 1926, when there were no other similar projects in Europe, and torn down in 1990) (Piplović, 1987; Piplović \& Franić, 2003; Uchytil, Barišić Marelić, \& Kahrović, 2009)

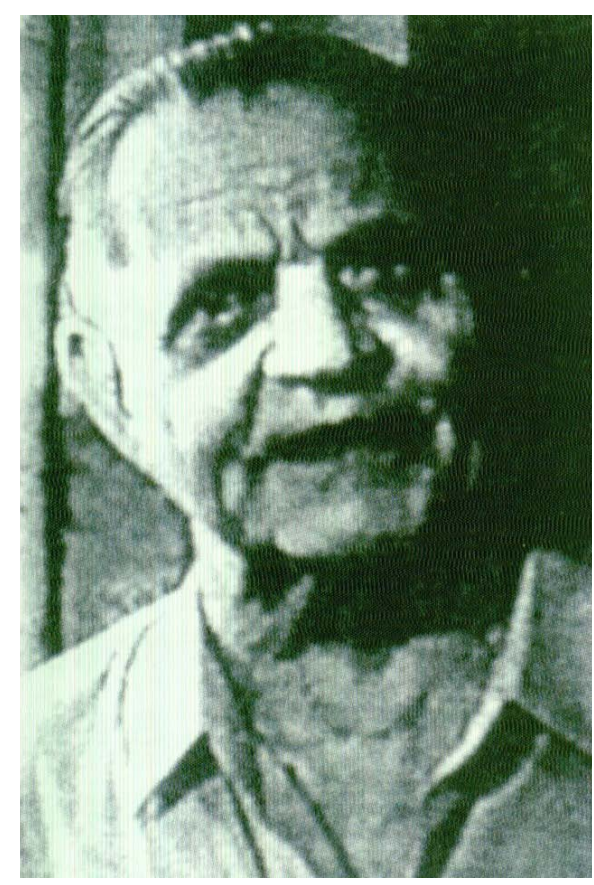

Figure 5. Josip Maria Kodl (1887-1971). Source: Plejić, 2003.

(Appendix 2). Stanko Piplović gave the following

description of Kodl's architectural expression (Piplović, 1987):

When planning buildings, Kodl would divide the functional units clearly, so his floor plans were expanded, and he would also carry out differentiation by height. Therefore, his structures usually consist of several different cubes with a playful but still calm rhythm and a clean expression. In terms of materials, concrete without the use of stone for the walls was prioritized, which distinguishes Kodl from his fellow architects, who were quite influenced by the local tradition. Almost all of his buildings have a flat roof, which was also a rare occurrence in Split at the time. 
The façades are plastered, and the surfaces of the walls between the openings are treated with visible bricks only in a few places.”

\section{Description of Kodl's electrical substations in Dujmovača}

Stanko Piplović describes Kodl's electrical substation in Dujmovača as follows (Piplović, 1987):

Resolving the issue of the electrification of Split and its surroundings and the supply of electricity from Dugi Rat, studies were conducted in late 1925 for the main distribution and transformer substation in Dujmovača, located along the Split - Solin road. The project for the substation was drawn up by Kodl. Some of its elements were located outdoors, while others were in a building with a rectangular floor plan built of concrete. In the central part of the building, which is higher and covered with a sloping roof, is a space for staff and measuring instruments. Cells with switching and control devices, transformers, and bypasses are arranged on three sides of the lower part of the building with a flat roof (Figure 6).

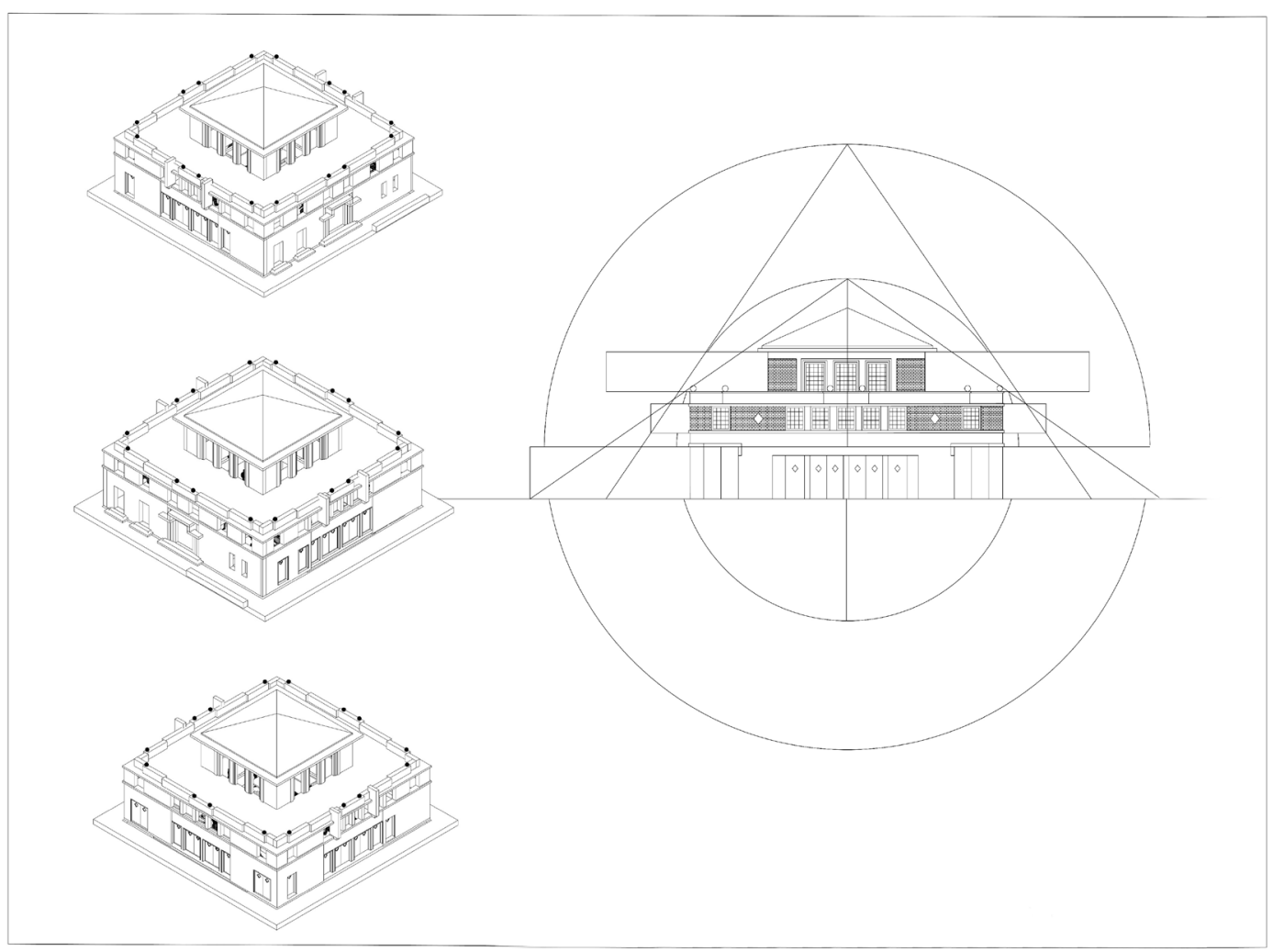

Figure 6. Display of the isometric view and façade of Kodl's main electrical substation. Shown from top to bottom on the left: west-south, south-east, and the north-west corners of the façade. The substation's height ratios with pedestrian viewpoints are shown on the right.

The electrical substation located on the address 70 Solinska cesta was built as the main substation. It is a one-story building with a regular square floor plan, a combination of concrete and brick with stone details. Its design as a whole, especially regarding the details of the openings, exudes the recognizable style of Josip Kodl. In the middle of the building, a 
higher volume of the square floor plan can be seen, ending in a hipped roof with a canopy pile cover and resting on protruding concrete eaves. The rest of the building is covered with a flat roof.

The ground floor is built of concrete and covered with plaster. The first story is built of bricks and features evenly distributed rectangular openings with smooth stone frames shaped in a grid of glass to achieve maximum illumination of the interior of this utilitarian building. Two openings on the main façade above the representative entrance are the only ones with wooden joinery, and they are not cut into the wall panel like the other openings. The unique interior with the substation elements has retained its original function to this day, although the substation itself is no longer in use.

The electrical substation located on the address 72 Solinska cesta (also designed by Kodl) differs from the main substation with its less decorative design and materials. "With its floor plan and height indentation in the form of cubic volumes, its flat roofs, and simplicity both in general design and in the details, it comes closer to the architectural expression of modernity brought to the Split architecture by Kodl” (Uchytil et al., 2009) (Figure 7). It

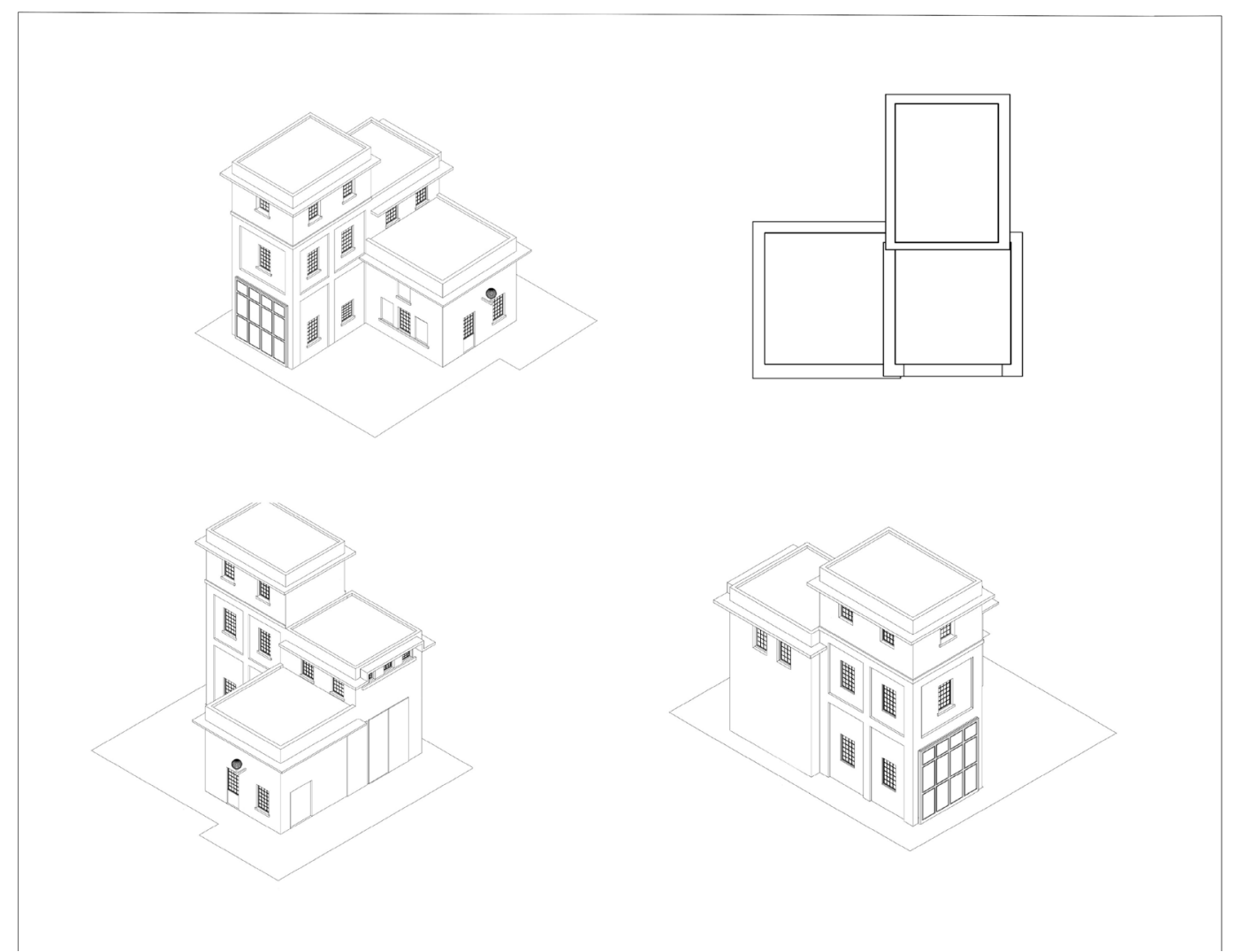

Figure 7. Display of the roof plan and isometry of Kodl's auxiliary electrical substation. The following views of its façade are shown as follows: north-west corner (upper left), west-south corner (bottom left), and east-north corner (bottom right).

is built entirely of concrete and consists of three basic cubic volumes of different heights, with the highest one having a high ground floor and two stories. "The main entrance is located in the lowest part and has only a ground floor, while the other part of the building has two stories. The [cubic volumes] all end with a prominent cornice with an attic and 
a flat terrace above" (Uchytil et al., 2009). Today, the substation is used as a warehouse (Appendix 3).

\section{The revitalization potential of industrial heritage}

There are several ways in which industrial heritage can be revitalized, and they will be reviewed by going through some notable examples (Pickard, 2017).

The Tate Modern art gallery in London is an example of how the Bankside Power Station, a historical site that was at risk of being demolished, was saved and reused in a way that fully preserved the old industrial building and its site. A modern annex was added to the building and the Station's turbine engine hall was preserved and transformed into an exhibition hall (Mollard, 2016).

Creating an industrial museum or an industrial exhibition on the industrial heritage location is another possible solution. This kind of venue is usually integrated with tourism and business functions. An example is the Jiangnan Shipyard in China, which was transformed and used in the Shanghai World Expo Park. It contains entertainment facilities that can become a large-scale industrial exhibition hall when needed. This approach also generates significant commercial potential, something that otherwise may be difficult to realize for industrial heritage sites (Minghang \& Guanghu, 2021). Likewise, the Slovenian Dravske elektrarne Maribor Company restored its old hydroelectric power plant Fala and turned it into a museum that represents the company's tradition and historical identity (Ifko, 2017).

Dutch researcher Ruud van der Kemp divided economic values of industrial heritage into those which are measurable (e.g. in Euros per square meter) which he termed "hard values”, as well as "soft values" which are non-measurable and subjective (van der Kemp, 2009). The Dujmovača heritage site mostly has soft values, since the main substation is no longer in function, and the site itself has deteriorated and is on the city's periphery. The soft values represented here are the relics of history that tell a story about the everyday life, habits, manufacturing and engineering methods, and aesthetics of the time period when it was in function. Kodl's work is also an important contribution to modern Croatian architecture. The site's potential to provide a sense of identity to the city of Split makes its preservation a valuable goal.

However, its location in an industrial area that has declined may be difficult to commercialize. The proposed solution must include a high-quality spatial development plan, one where all the soft values are successfully showcased and integrated into both the site itself and the program design.

\section{Elaboration and context of the proposed solution}

This paper is based on an earlier initiative to establish a science museum, but it extends that idea to the establishment of a Science Center that would include a science museum as well as a research and congress center. In Split, such an institution would serve as one of the centers of cultural events and an important link in encouraging the development of the city towards the northern coast. The aim of the project was also to showcase the poten- 
tial of Dujmovača, which has been, until now, a forgotten space. The goal was to highlight Split's rich industrial heritage as a historical location was used to design new content for the city.

The envisioned building seeks to unite the industry of the past to that of the future, meaning that the Science Center in Dujmovača would be a hybrid of a scientific and a cultural-educational institution promoting scientific work and encouraging the development of culture through congresses, exhibitions, lectures, networking events, and fairs. As such, it would act as a transition point between university education and the real economy sector, both for young people and the "older" generations of engineers and entrepreneurs who want to keep up with the times (Nikolić, 2017).

\section{Macro and micro urban morphological analysis}

The designated project site is in Dujmovača, spread across about 14,200 $\mathrm{m}^{2}$ in the IS6 Zone: transformer substation (infrastructure system areas) based on the 2007 Amendments of General Urban Plan of Split (GUP) document (City of Split, 2007) (Figure 8), comprising cadastral parcels no. 930/1, 932/2 (Kodl's main substation), and 932/3 (Kodl's auxiliary substation), as well as parcels 930/2 and 931/3 for vehicle access. The surrounding area is part of the economic zone, also based on Split's GUP. According to Article 23 of the GUP, cultural facilities may be built at these locations:

If their locations are not defined elsewhere, buildings for public and social enterprises may be built in other zones where this is permitted, and their location may be determined by developing detailed spatial planning documents and applying relevant standards. When public and social facilities are built in zones designated for other uses, they shall be governed by the requirements regulating public and social facilities in the relevant zone, as defined by the Urban Rules (City of Split, 2015a).

The land parcel contains Kodl's main electrical substation and a smaller, auxiliary substation, as well as another, modern substation that is currently in use (Figure 9). The western part of the parcel contains a park ringed and protected by tall cypress trees, and features Kodl's two buildings. One of the main features of the site is its introversion with regard to the original, utilitarian purpose of the substation (Appendix 1).

The project intervenes on about $9,200 \mathrm{~m}^{2}$ of this portion of the parcel. The eastern part of the parcel contains the currently operating substation with an outdoor disposal site (utility poles, wires, metal sheets) and a grounded concrete block with electrical installations connected to the main transmission tower that forwards the power network. The transmission tower, approximately $25 \mathrm{~m}$ high, is visible from the eastern part of the Solin-bound road (Solinska cesta) as an unmistakable spatial benchmark and a feature of the recognizable industrial setting (Figure 9; Appendix 1). The drawbacks of the chosen location are its limited size and unresolved legal property relations that would require partnership and cooperation with the Ministry of Culture of the Republic of Croatia, the local government and HEP, the national energy company (Arhitektonska radionica centar d.o.o., 2015; Ivanišević, 2010). 


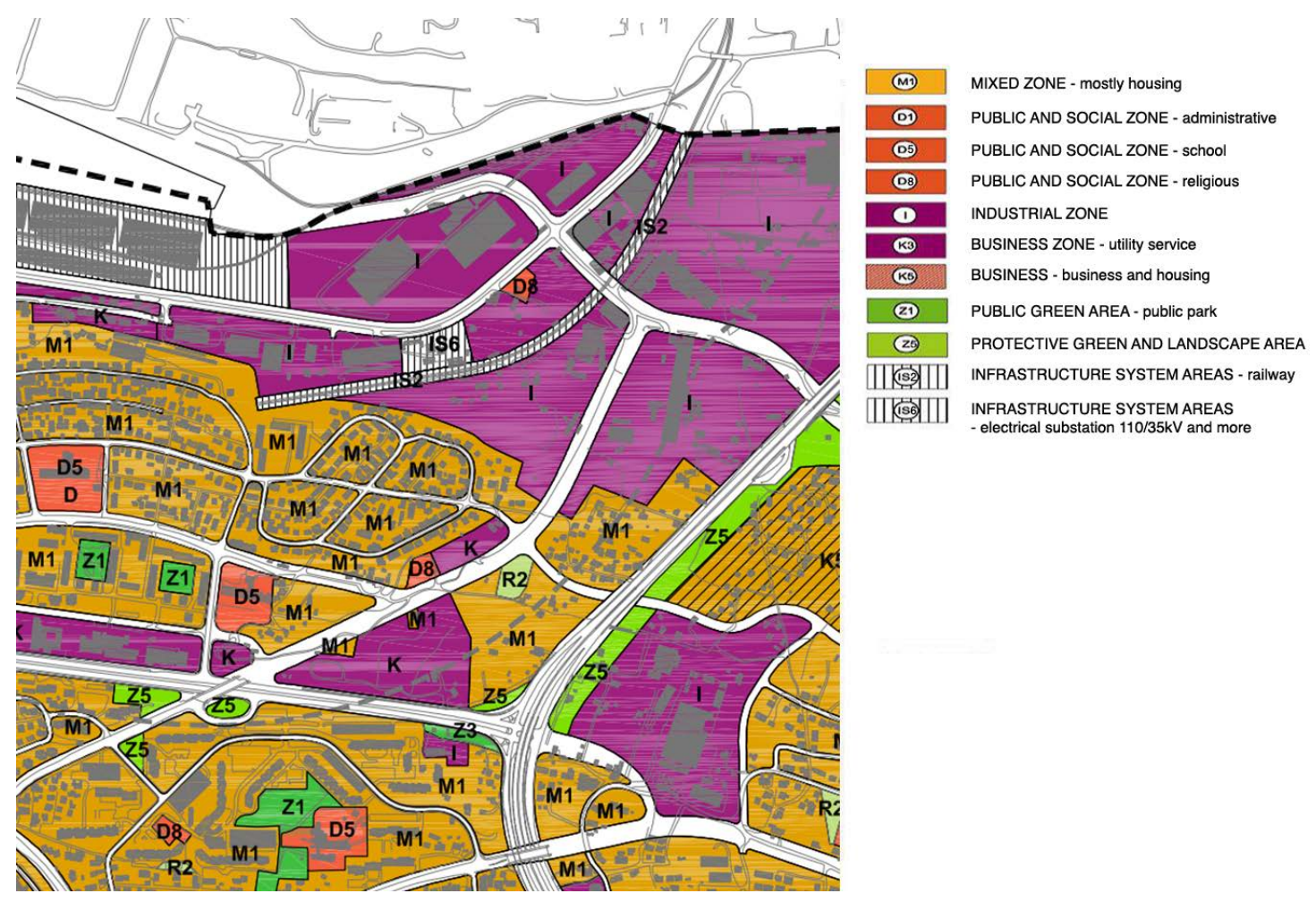

Figure 8. 2007 Amendments of the General Urban Plan of Split: Spatial Uses and Intended Purposes. The location of the transformer substation (infrastructure system areas) is marked by "IS6". Source: City of Split, 2007.

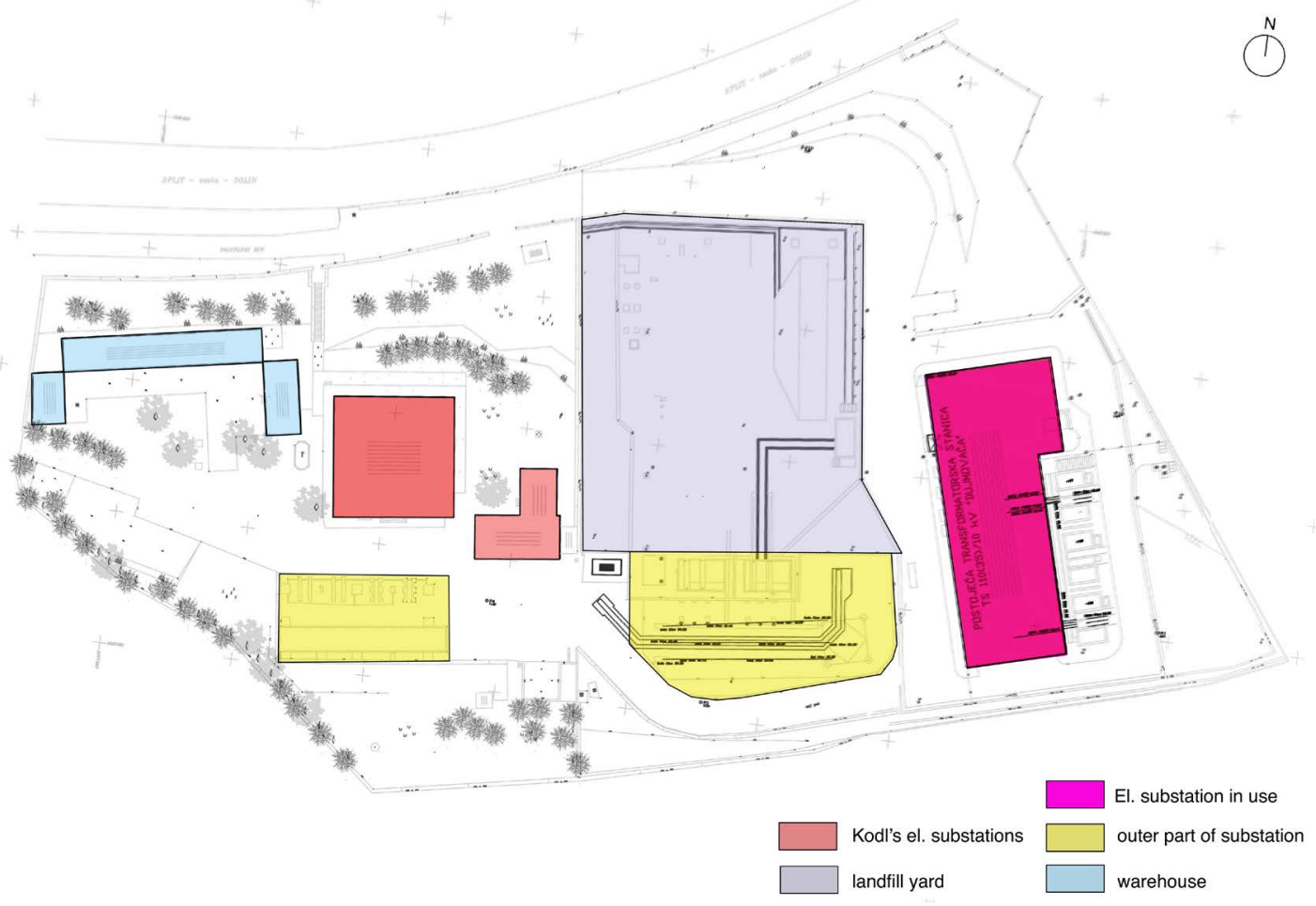

Figure 9. Parcels (930/1, 930/2, 931/3, 932/2, 932/3 k.o. Split) that make up the proposed site of the Science Center project. The site is outlined by Solinska cesta in the north, and the only existing access road lies in that direction (shown in white). The northern side of the road is lined by commercial warehouses ("Brodomerkur" trading company, not shown). The southern border of the parcel is skirted by a railway, with the neighborhood of Neslanovac just across (not shown). The railway enters a tunnel $300 \mathrm{~m}$ to the west of the planned Science Center site, in the direction of the city center. 
In the near future, if the railway connects the Split city center and Split Airport ( $6 \mathrm{~km}$ from the town of Trogir and $25 \mathrm{~km}$ from the city center), the Science Center site would become one of the stations on that route (see Figure 2). There are strong reasons to build a railway station there, as this would connect the Science Center - thus giving rise to a cultural hub - as well as Dujmovača and the town of Brda to the Split center, Solin, Kaštela, Trogir, and the Split Airport, thus forming a large conurbation (Split Portal, 2013; Ahac, Lakušić, Ivančev, \& Čudina, 2017).

To the east of the existing substation, lie private land parcels, most of them abandoned and neglected. The Romanesque St. Domnius' Chapel stands just a short distance away. A parcel $\left(12,430 \mathrm{~m}^{2}\right)$ with warehouses (Dalmacommerce d.d.) in the western part of the location shows potential for expansion of the Science Center in future stages (see Figure 4). The possibility of phased construction and expansion will depend on the sustainability of the Center and the potential development of the northern side of the Split peninsula.

\section{What is a science center?}

Science centers provide meeting spaces for the community, allowing its members to create, consume, and communicate about science. These centers - unconventional spaces for socializing, relaxing, talking, meeting, producing, presenting, educating, counseling, and informing - create a sense of belonging and solidarity in the community. The main idea is to provide a self-guided experience for the visitors of the center, as well as to include interactive content in order to enable practical and interactive learning, rather than just reading the information. Visitors also have the opportunity to participate in science mini-workshops and various projects, as well as to meet national and international scientists (Homadovski, 2009; Šulc, 1989).

A science center is a space for showcasing and testing cutting-edge technologies and innovations, as well as socializing, and as economic and cultural development. Its construction should be technologically advanced and innovative in order to enable the installation of state-of-the-art technologies and systems even after the construction of the center. It should also be designed for long-term evolution over its lifespan (Museum Planner, 2013). Therefore, a science center should be an example of interdisciplinary and interconnected design, combining a cultural center and a scientific institution.

The science museum section of a science center is an example of a new generation of museums employing a "hands-on" approach to the intersection of culture, education, and science. Namely, science museums are innovative museums that strive for new forms of presentation, interactive learning, and spatial organization. They monitor technical and scientific achievements in the fields of natural and technical sciences, medicine, and engineering. One referent example is the Swiss Science Center Technorama in Winterthur, founded in 1982 (Swiss Science Center Technorama, 2021).

The proposal of the Science Center's departments would be devoted to various scientific fields and could be subdivided based on other factors, such as prominent scientists (Croatian and international), Croatian patents, ongoing research projects/the future of science, simulations, and showrooms. This can be planned according to the general goals and features of science centers (Table 1). 
Table 1. General goals and features of science centers (aFRONT Spatial Innovation Institute, 2018)

- Contributing to the promotion and popularization of science;

- Fun and didactic learning;

- Interactive and open exhibitions;

- Organizing training programs for teachers/students/youth;

- Showcasing scientific and technological growth and its application in different industries;

- Showcasing and testing innovations and providing innovators with their first credentials on the market;

- Engaging the local community, networking, and connecting with visitors;

- Providing a transdisciplinary platform for other activities in the field of education studies, including social sciences, arts, and culture;

- Establishing for-profit and non-profit relationships as part of exhibition development;

- Enabling the involvement of corporations and providing space for cooperation between experts and entrepreneurs on the development of new technological, design, marketing, and other business solutions;

- Raising visitor awareness of the importance of sustainable mobility by reducing the number of parking bays for motor vehicles and promoting alternative access routes;

- Adding to the tourist attractions of the city, as well as the entire country.

\section{The programmatic content of a science center}

In order to design the space and content of the Science Center, it is important to briefly review the essential elements that are contained within a science center, as shown in the general schematic diagram in Figure 10. In general, programmatic content rooms are key spaces for a science center's activities. They have to be interconnected, to allow for dy-

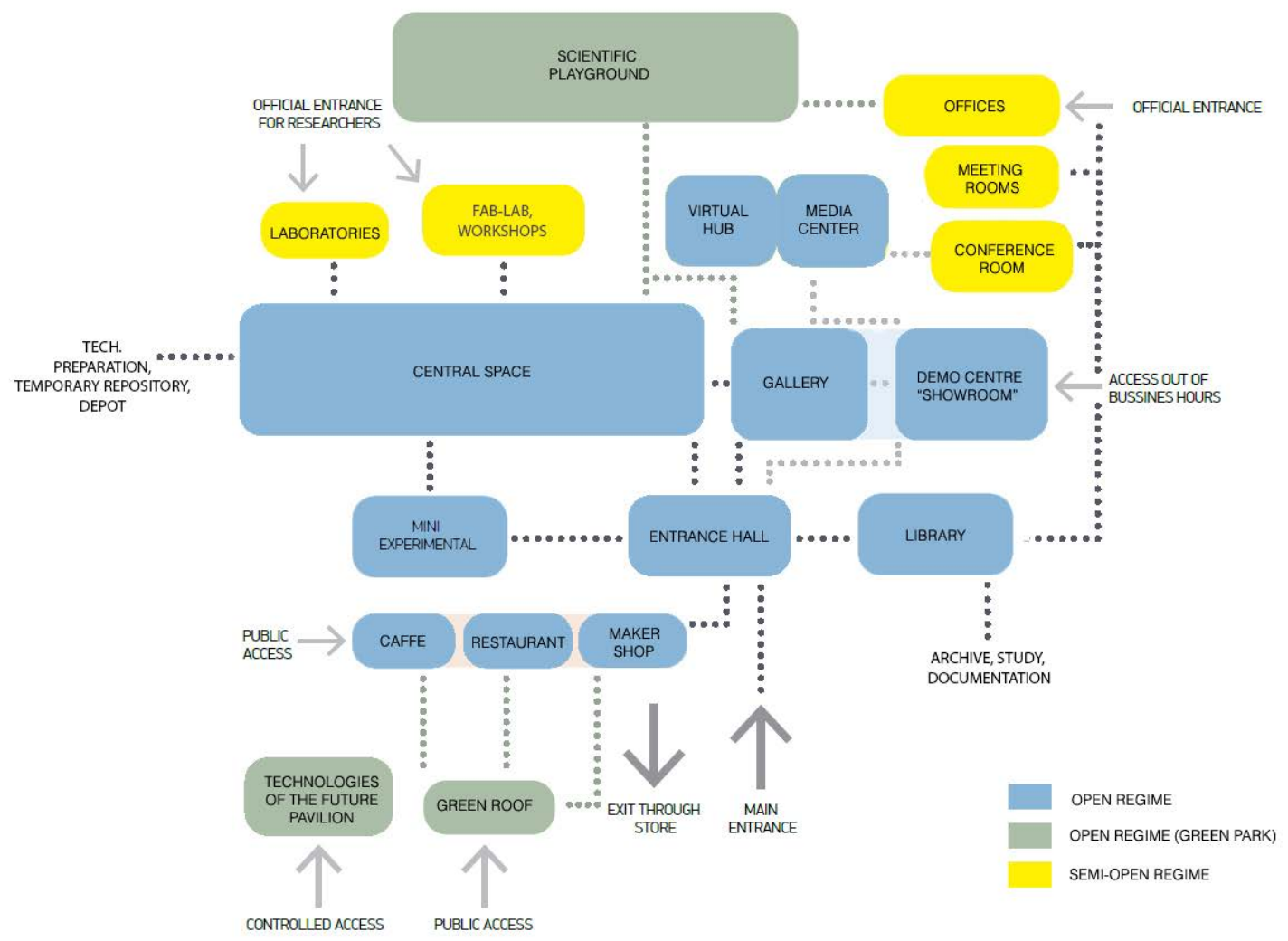

Figure 10. A basic diagram showing the functional sets, connections and required access points in a science center. The diagram is modeled on a reference tender from the Ljubljana Science Museum (aFRONT Spatial Innovation Institute, 2018). 
namic adjustment of the exhibit setup, and to be dividable into smaller units (to provide smaller, daylight-free areas in daylit rooms). They should be adapted for physical and virtual exhibitions. Freight elevators and service and transport routes within the building should be planned to avoid disturbing the visitors, but also to allow experts to work while the center is open for visitors (aFRONT Spatial Innovation Institute, 2018) (Figure 10).

The central space

The central space of a science center is designed and intended for learning about scientific, technological, and cultural concepts in a way that is understandable to different age groups and people with different educational and professional backgrounds. It contains specialized (permanent) exhibits, satellite products, and rented exhibits. Some exhibits may require dimming to work. The exhibits are the main feature in this space and must allow for the unimpeded movement of visitors around the room. Some exhibits are equipped with benches and chairs to allow visitors to observe the program or rest. The number of exhibits is more or less permanent.

\section{Gallery}

The gallery hosts temporary exhibitions from similar centers, other researchers, corporations, artists, and/or collaborating festivals. It should be located near the café and the restaurant. It also features a flexible room to store equipment for interactive presentations. The room should be reasonably spacious and suitable for the installation of bulkier exhibits, with a ceiling capable of supporting heavy loads. The space must be accessible to visitors outside regular working hours of the Center. The number of exhibits is variable. Larger exhibits also need a separate delivery area adapted for their size.

\section{Laboratories}

Under the guidance of laboratory assistants (e.g., university students), laboratories run experiments to provide learning opportunities for visitors about the fundamentals of various scientific fields. This requires basic laboratory equipment. Each laboratory is a functionally equipped space for conducting experiments and their presentations to smaller groups (up to 16 visitors). Laboratories are directly connected to preparation and storage spaces.

\section{Fab lab}

The "fab lab" is a prototype of a laboratory and creative space dedicated to research and development in the field of engineering, with an emphasis on the do-it-yourself ("DIY") approach. Part of the time, this space is dedicated to research and development by its users, while the rest of the time it can be dedicated to small groups of visitors who booked the space beforehand. The fab lab can be used by corporations and researchers, as well as other organizations and institutions, to quickly prototype and present their work to visitors.

This requires the installation of workbenches/stations to hold basic electric or computer equipment or simple material processing tools. The room should be designed for the installation of dust-generating machines (small saws, grinders) and clean machines (com- 
puter numerical control machines), as well as the installation of electrical engineering tools with computer equipment and the use of basic electrical equipment (soldering irons, measuring instruments, power supplies).

\section{Showroom}

The showroom is designed to showcase company products and business activities. The space has to be open to visitors outside the regular working hours of the Center and have the option of fully blacking out the light in the room. The ceiling should be capable of supporting more than standard loads to support heavy exhibits. The number of exhibits is variable.

\section{Conference hall}

The conference hall is designed to showcase projects and research and host thematic meetings and conferences. It provides supporting space for the supplementary program of the Center as well as for independent events.

\section{Media center}

This rentable space is designed for journalists and external users (corporations, protocol visits, etc.). It also satisfies video and audio streaming needs of the Center. A designated, fully-equipped modern recording studio is a part of this space.

\section{Mini experimental room}

The thematic mini experimental room is dedicated to the youngest visitors and offers childcare services. The room is adjacent to the central space, the entrance hall, and the café for practical reasons of parental oversight. It specializes in experiments and exhibitions tailored to preschoolers. The emphasis is on sensory and creative spaces.

\section{The design approach}

Based on the resources and capacity for adjustment in the city of Split with regard to urban and functional changes, architectural solutions are required that are not limited to any predetermined programmatic content or architectural typology. In real life, the narrative is typically nonlinear, so the design methods used should not follow a linear, fixed approach; instead, they should focus on a constant "dialogical narrative between different design methods and the theoretical groundwork" (Sennett, 2016).

\section{Functional diagram}

A science center is a hybrid between the typology of a museum and social center, involving interactivity, participation, and a sustainable business system. A science museum, constituting a part of the science center, requires solutions for exhibit maintenance and delivery, as well as a clearly defined arrangement of visitor movement. 
Different spaces in the science center can be divided into open, semi-open, or closed access areas based on museum functions and the visitor access regime, as well as the staff assigned to each of the functions. This division permits the analysis of the structure of museum content and the definition of its relations within each access area, as these determine the primary structural division of museum spaces, and, consequently, the effectiveness and design of the science center (Maroević, 2002) (Figure 10).

The open access area focuses on the interaction between museum exhibits and visitors as well as on learning, rest, and entertainment as it is open to the public. It includes a space for permanent and temporary exhibitions.

The semi-open access area is dedicated to the administration and management as well as the study, identification, and preparation of museum exhibits. Visitors may or may not be allowed to move between the open and semi-open access area; if they are, this must be well-managed. Visitor access to the curator's rooms, museum administration, storage

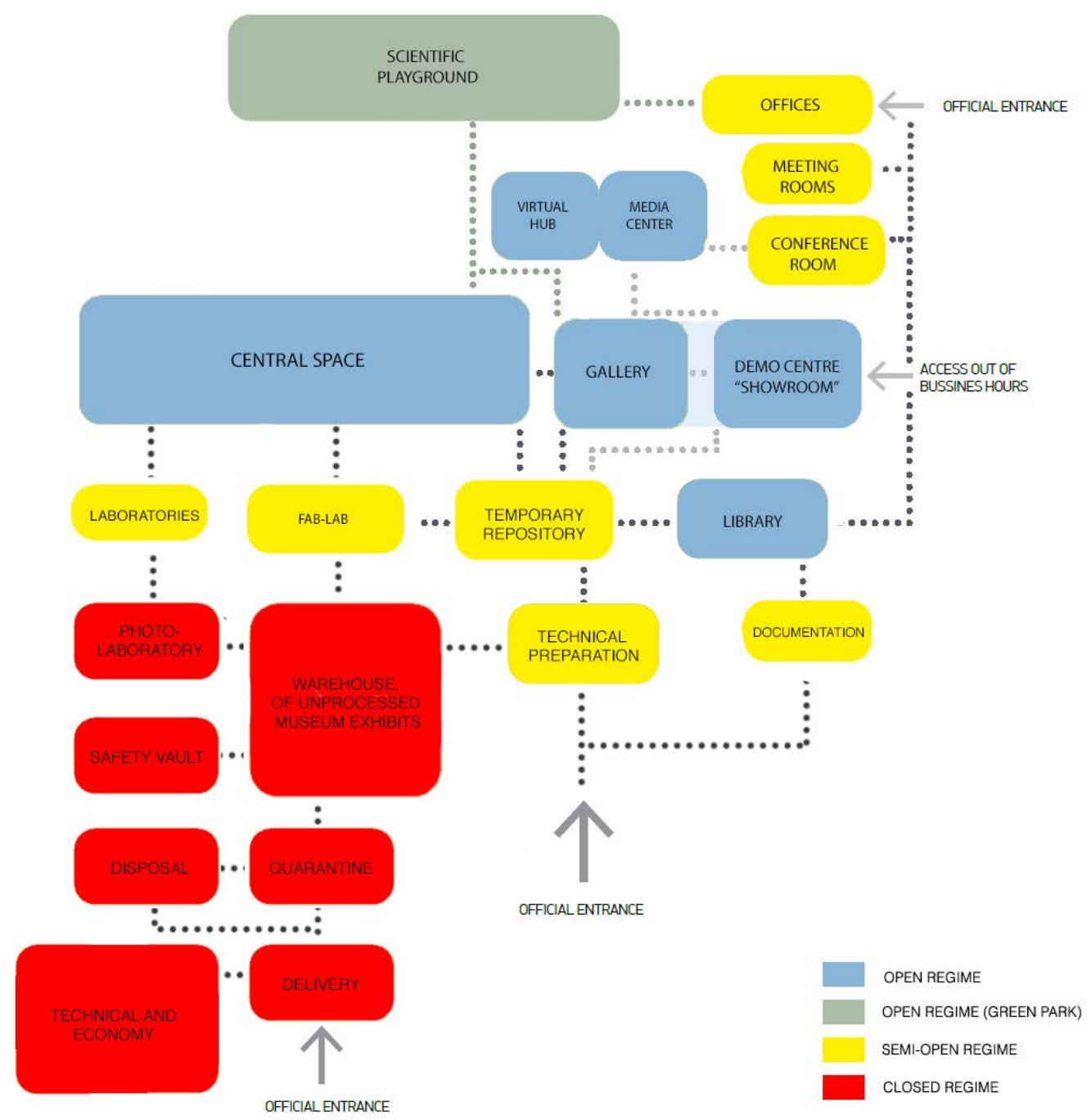

Figure 11. The diagram of functional sets and the division into three access areas: open, semi-open, and closed. 
rooms, workshops and laboratories must be supervised and clearly set apart from the main museum entrance.

The closed access area involves the reception, disinfection, and storage of museum pieces, as well as technical and business areas of the museum. Visitor access to the closed access area must be strictly supervised and limited as much as possible - the visitors should always be accompanied by a staff member (Figure 11).

Movement within the science center can be divided into three basic types, two of which are movement of people (scientists/employees and visitors), and the other one being the movement of materials (e.g., exhibits). The movement of visitors and museum exhibits must be managed, and their paths should not cross (Maroević, 2002).

\section{Attitude towards the architectural context and legacy conservation}

When approaching the revitalization of industrial heritage, it is important to decide if a simple renovation is sufficient or whether reprogramming the original function is necessary to integrate the building into the vital system of the new complex. Any interventions must preserve authenticity by leaving as many of its constituents in place as possible (ICCROM, ICOMOS, IUCN, \& UNESCO, 2013). Croatian conservation guidelines call for the restoration of Kodl's legacy, an unobtrusive appearance of any new buildings, and an unambiguous attitude toward the existing legacy (Ministry of Culture of the Republic of Croatia, 2012).

The limitations of the land parcel and its size determine the optimal relationship between the factor of built land and the spatial and programmatic requirements. Consequently, satisfying the spatial and programmatic content requires one to devise two different conceptual approaches to Kodl's buildings: the first option being called the "house in a house" model, and the second the "pavilion in a park" model.

The house-in-a-house conceptual approach espouses the relationship that places Kodl's main substation within a larger, closed system - in this case, the Science Center complex. This potentially calls for a single, vaulted or hovering construction over the entire system. Early in the design process, a study version was created using this model and included a visual interpretation of the resulting proposed solution (Figure 12). However, although it is not uncommon for industrial heritage reuse to involve such interventions to the original heritage elements (Minghang \& Guanghu, 2021), in a location such as this one, the approach required could be seen as more aggressive or radical, as well as possibly incompatible with conservation guidelines.

Another way to preserve industrial heritage is to keep main industrial buildings in the center and develop the surrounding environment to form a theme park that reflects and complements the industrial history of the location. An example is the Zollverein Coal Mine Industrial Complex in Essen in Germany after the revitalization plan was implemented in 1989 (Minghang \& Guanghu, 2021; UNESCO, 2021). This is also reflected in the conceptual approach that the author devised and named the "pavilion-in-a-park" approach.

The author's proposed "the pavilion-in-a-park" conservation approach thus embraced a more open relationship where Kodl's main and auxiliary substations are an indepen- 

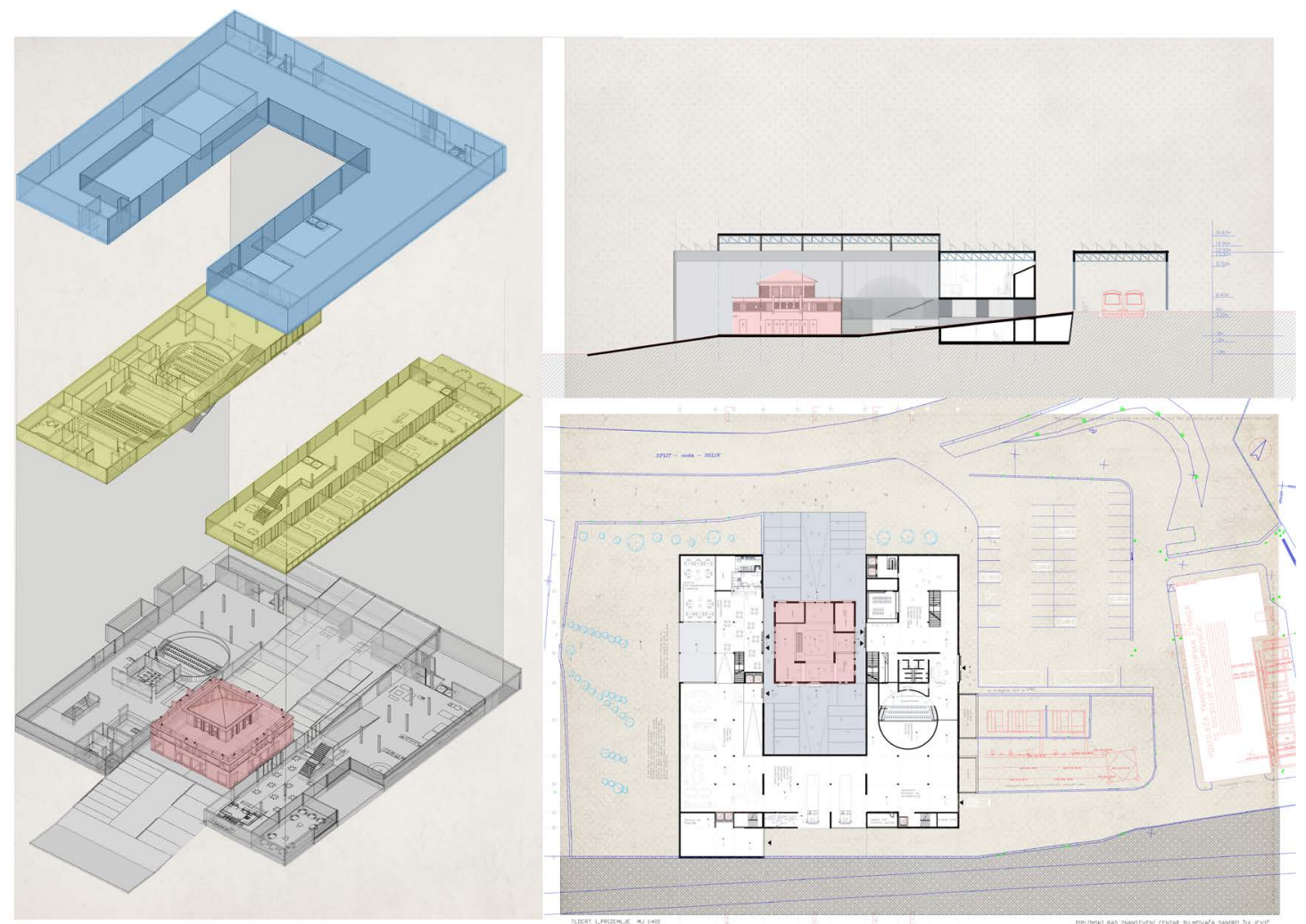

Figure 12. Visual interpretation of the "house in a house" model. Kodl's main substation (shown in red) functions as an integrated part within the new building. Shown here: the central space (in blue), science institute with laboratories (in yellow), and other functional zones that make up the proposed Science Center complex.

dent unit within a larger system, allowing them to function independently of the rest of the Science Center. This sort of approach places them in a central and highlighted space, allowing the buildings to retain their authenticity, as well as a location of importance. Choices on how to arrange and add new functional units would be derived from this approach. This decision directly affects the structure of the building, its construction, and the choice of materials (Figure 13).

In this case, the decision was made to use the pavilion-in-a-park approach, which then further implies foregoing the central exhibition space in favor of content structured around the main substation using smaller scenes that interact directly with the inner courtyard/ park and the open-air exhibition. At the same time, this offsets the visually limited area of the site, as it can be expanded or connected with outdoor events, and the individual units do not dominate over the legacy buildings. Both the main and auxiliary substations would remain a part of the central inner courtyard/park, but also divide it into smaller sub-units (Figure 13; Appendix 4).

\section{Spatial ratios and proportions}

Environments must be studied before they are built: "Equally, we build in order to think and act" (Preziosi, 1983). The relationship is essentially dynamic and reflexive. In the proposed solution, initial control over the space was established by using an orthogonal raster as a starting point for any further designs. An orthogonal raster was also used as part of the analysis and design methods. 


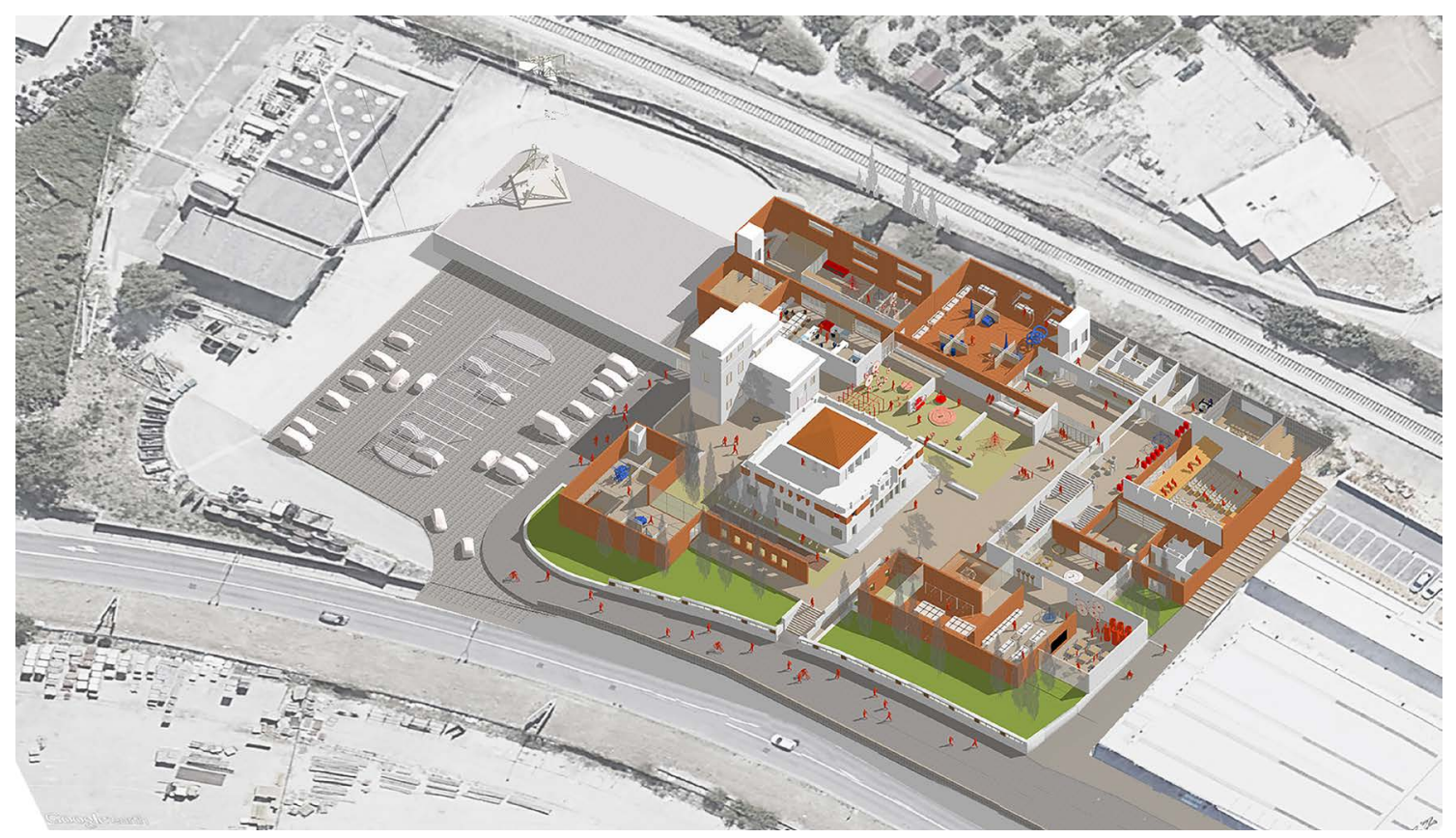

Figure 13. An isometric drawing of Kodl's substations as part of the central courtyard and their interaction with the planned Science Center. The figure shows the ground floor of the Science Center.

This need for a component that would establish basic order and create clearly defined functional interrelations was reinforced by the morphology of buildings at the Dujmovača site. Their arrangement is irregular, and this is evident even on a larger, urban planning scale. For this reason, the orthogonal raster was laid down to help streamline and emphasize the interrelations between the existing buildings and the planned new buildings.

Figure 14 shows the size ratios and proportions, as well as the interaction of Kodl's substation with the remaining alterable space. The orthogonal matrix may also be used to determine the appropriate span of the load-bearing structure, which is then used as a modular system. The square field framework of a regular raster was reciprocally reduced and divided into smaller units or "rooms", where the substation occupies one of the modules. All other modules were divided into reciprocally smaller units, as needed.

The conservation approach defines another vital and fundamental setting of the space: the visitors are able to observe the whole substation; it does not fade away in the background but is highlighted instead. The proposed distance from Kodl's substation for the intervention is half the module of one substation, or $9 \mathrm{~m}$ ( $1 \times$ construction module). One module occupies $1 / 4$ of the area of Kodl's substation, which equals the size of the central roofed atrium. The side of the square module is $9 \mathrm{~m}$ long, corresponding to $1 / 2$ of the transverse length of the substation.

The buildings' sizes should be calculated based on the size of the human body. Additionally, human visual perception should be considered a relevant factor when scaling the grid. Scaled in this way, the size of the orthogonal raster grid directly correlates with the target points of Kodl's substation, as the whole façade and volume of the substation is visible from an unobstructed pedestrian line of sight at the distance of $9 \mathrm{~m}$ (see Figure 6; Appendix 4). 


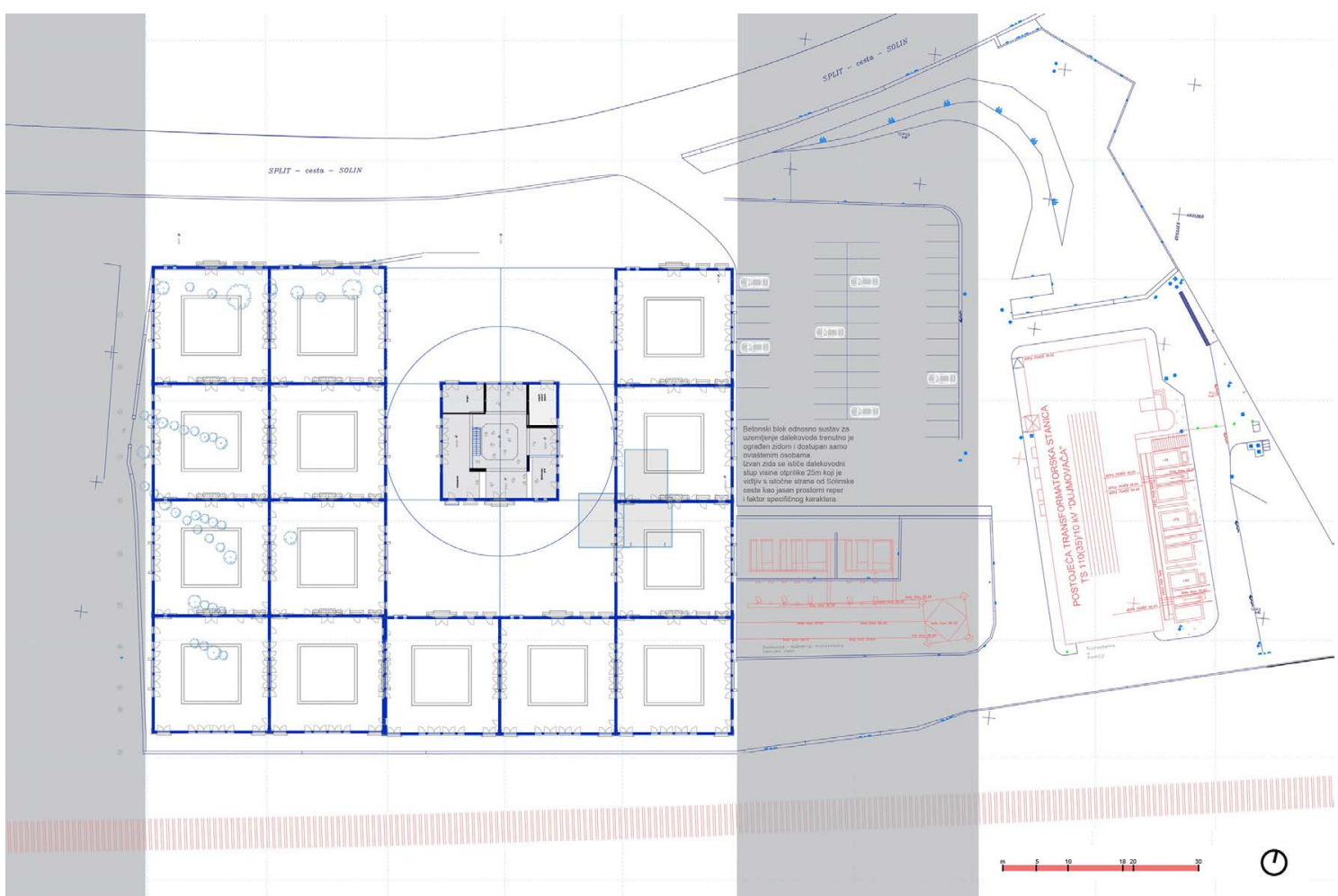

Figure 14. The interrelation between Kodl's substation and the rest of the intervention area. The striped red line on the south border of the parcel indicates the railway line.

\section{Conceptual definition of boundaries}

Based on the design approaches described above, the conceptual scheme of the Science Center can be articulated while observing the conservation guidelines for Kodl's substations. Therein, the author followed the guiding principle of Alvaro Siza: "The museum architecture is ideally free of walls, doors or windows, or any other overly conspicuous, over-scrutinized, and redundant obstacles” (Siza, 2006).

In his search for conceptually articulated architecture, Siza uses the geometric plane as an intangible abstraction and a basic module that rejects the semantic dialog of historical styles and embellishments. The wall surface is viewed as an abstract boundary of volume and geometry. The radial structure of walls, which are understood as layers around the central pavilion or Kodl's substation, provides a measure of privacy and creates a spectrum of moods, sounds, and sights, extending from the surrounding context toward the center (Figure 15).

The ground floor plan (Figure 16) shows that the boundary between open and closed space is not strictly defined due to the layer-like constellation in which the walls are set. The gradation between the outer and inner space with "in-between" zones softens that boundary and any sudden transitions. In this way, the inner courtyard/park expands into the "pores" of the structure and invites observation and exploration.

\section{The relationship between the concept and the articulation of details}

Metal structures in industrial environments have a noticeable quality of "lightness", which gives the impression of transparency. In contrast, park architecture often has a grounding, massive, or static quality. To find a method or a common ground for combining or com- 

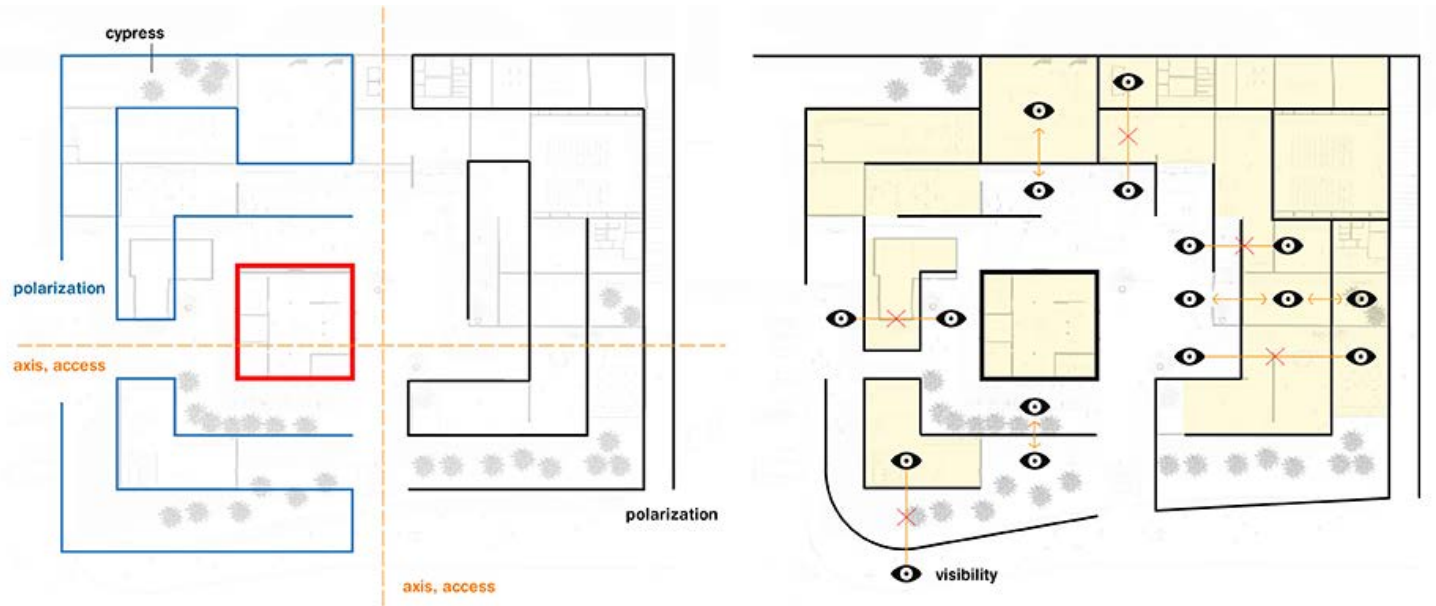

Figure 15. A conceptual representation of the structure as layers around the central pavilion, or the so-called "onion effect”.

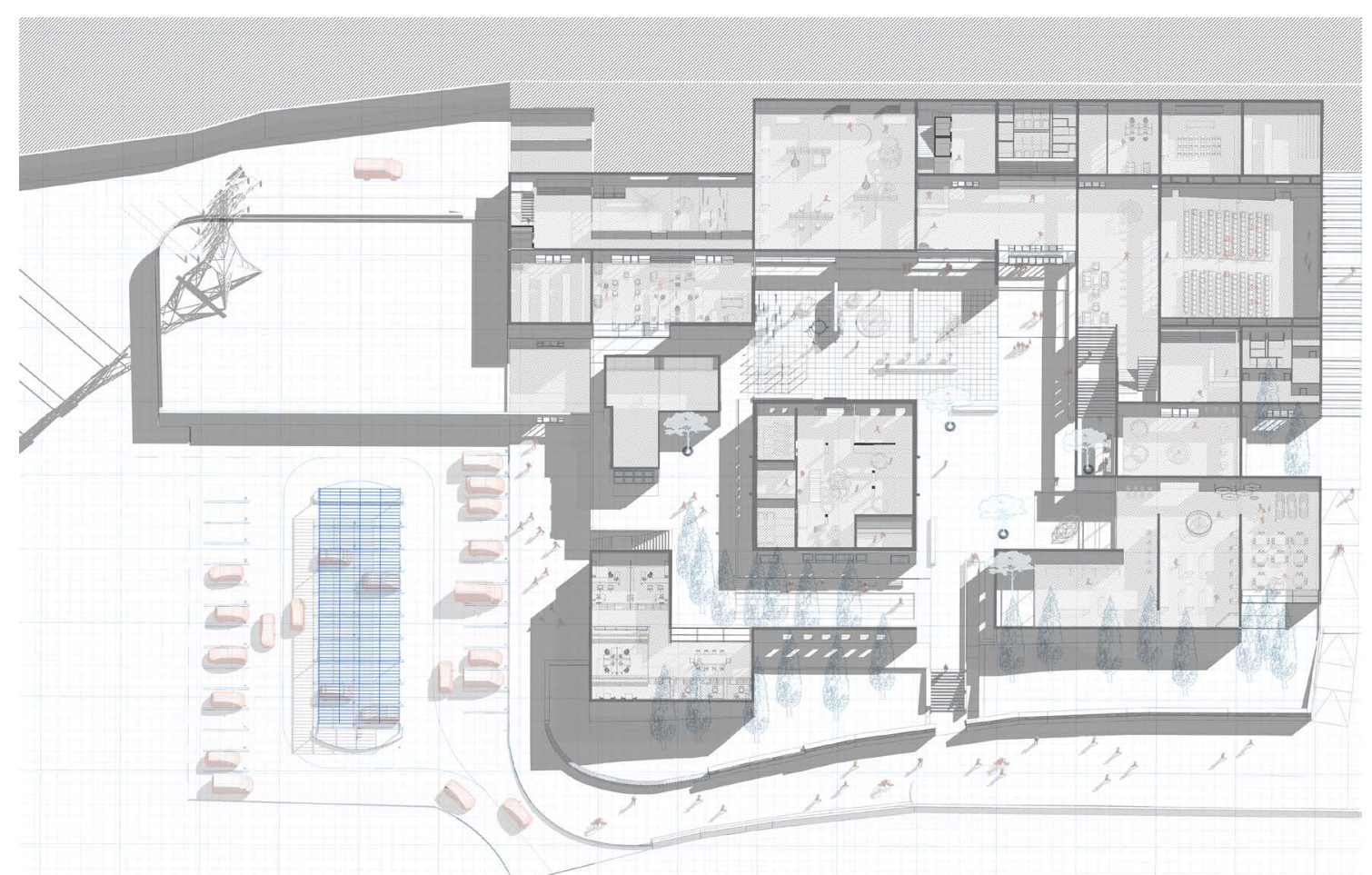

Figure 16. The ground floor plan of the proposed Science Center and an illustration of the relationship between solid space and void, or the internal and external surface of the space. The orientation of the image is south (top) to north (bottom of the image).

pounding these factors, it was necessary to identify which elements contributed to the industrial mood and which were characteristic of Josip Kodl's park architecture (Hafner, 2002).

The design concept is reflected in the floor plan depth (see Figure 15), generating the need for zenithal lighting and a contact point or association with the industrial context (Figure 17). Zenithal lighting is not only a natural lighting solution but is also a replicating element that accentuates or connects different parts in a single whole using a familiar pattern, by combining a light metal-and-glass roof structure with heavy brick and concrete walls (Figure 18). The roof contains photovoltaic cells for the purpose of architectural aesthet- 


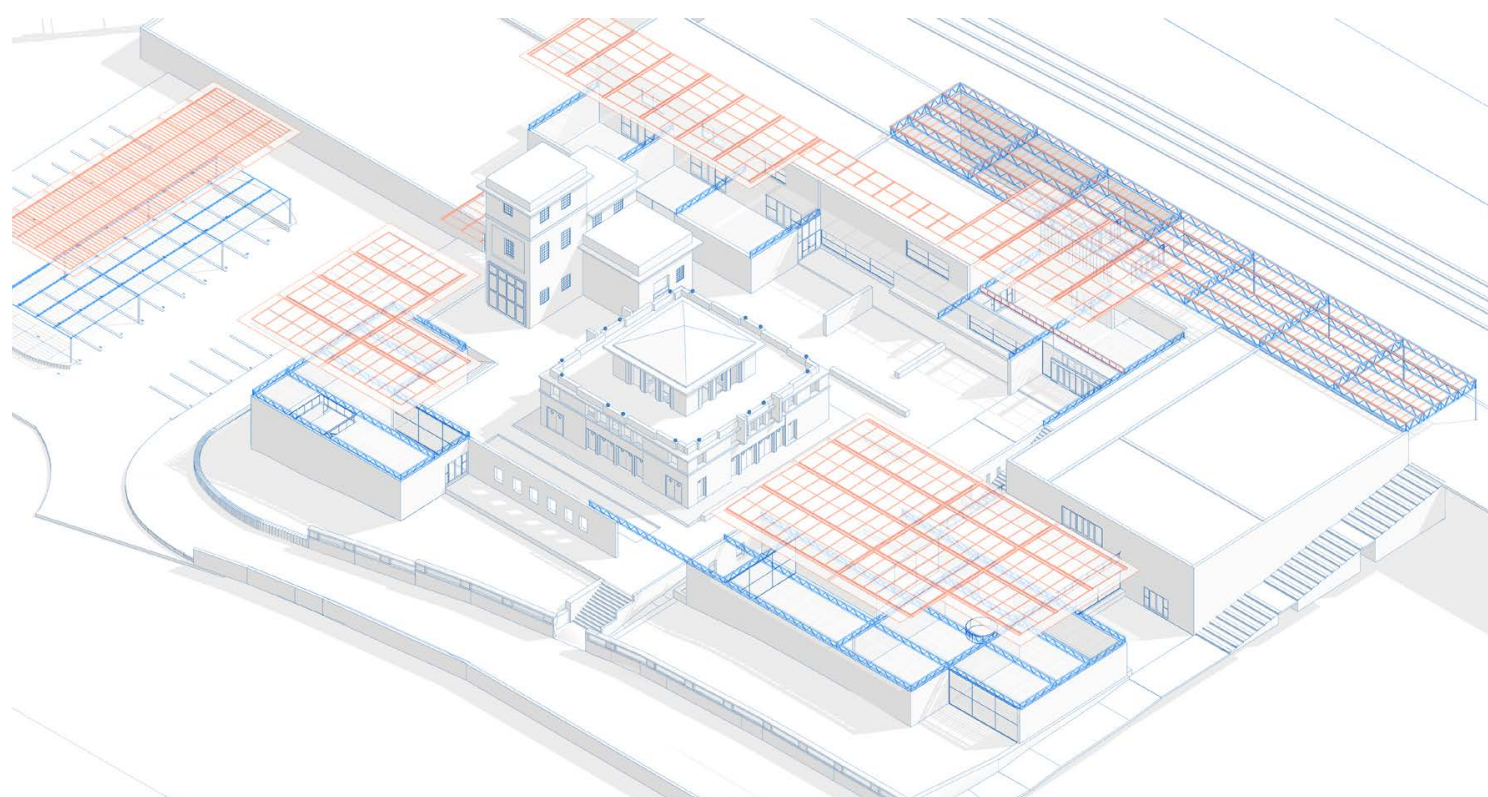

Figure 17. An isometric projection of the entire building with photovoltaic cells (light metal structures shown in blue, glass roof structures in red) and the railway station (upper right corner of picture, along the rails).

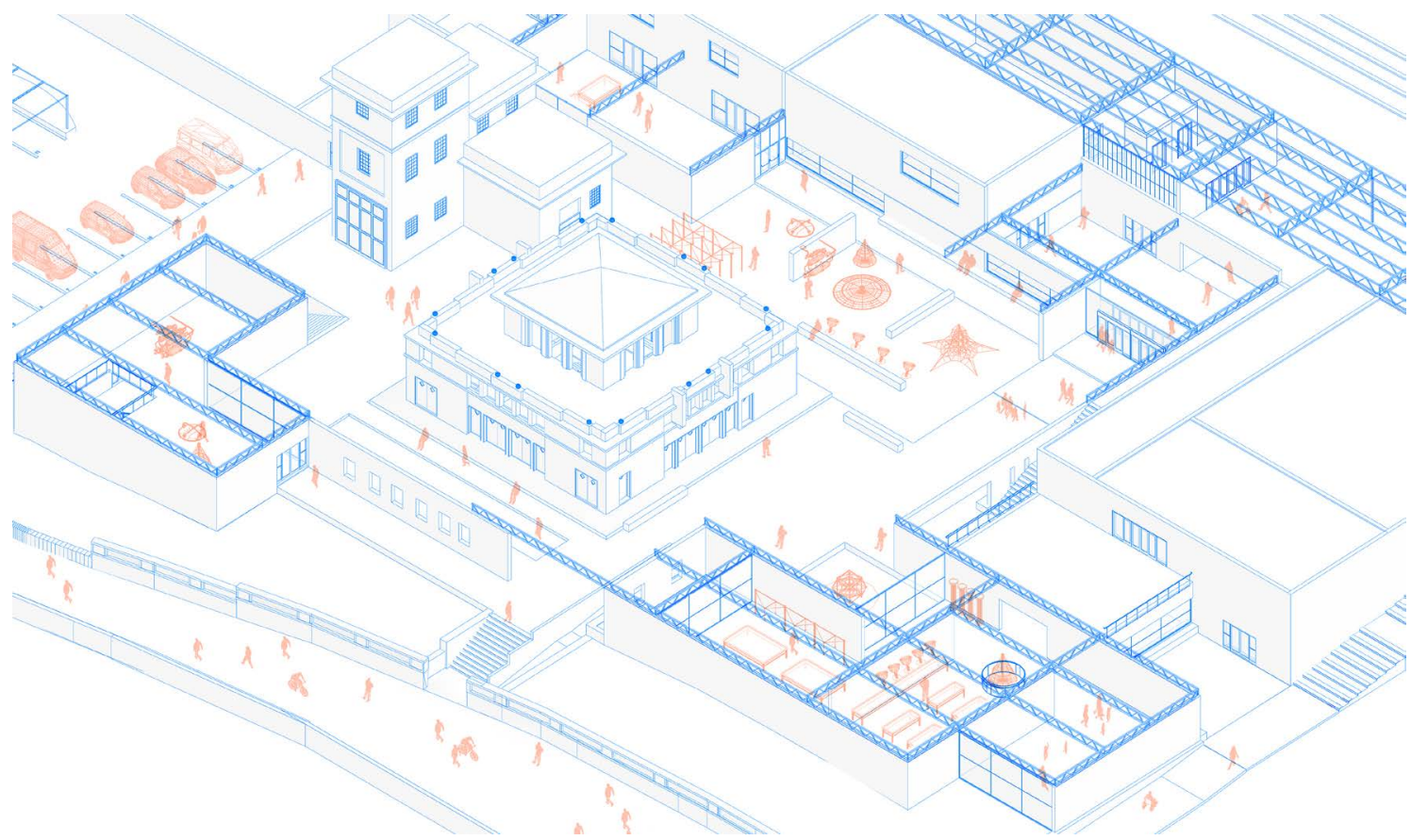

Figure 18. An isometric projection of a light metal structure over brick and concrete walls. Illustrated here are also the locations of outdoor exhibitions and modifiable outdoor content.

ics and sustainability. Typical examples of this solution are the renowned contemporary arts museums in Houston (1986.) and Riehen (1982.), designed by architect Renzo Piano (ArchDaily, 2011; Fondation Beyeler, 2021).

Based on how they interact with the roof surfaces or zenithal lighting, spatial volumes can be divided into "served and servant spaces", or open access areas (the entrance hall, permanent and temporary exhibitions, workshop) and restricted access areas (administration, polyvalent hall, 3D lab, laboratories, library, storage archive, wardrobe, toilets, and utility rooms) (see Louis Kahn in Janson \& Tigges, 2013). 
For load-bearing walls, the project used a combination of concrete and brick - which is an inversion of the material used by Kodl (Figure 19; Appendix 5). A part of his original brick wall with details around the entrance is also preserved (Appendix 1). In addition to their constructive and aesthetic value, "materials and surfaces thus gain an additional, archetypal and symbolic value, as well as the value measured by the passage of time” (Pallasmaa, 2000).

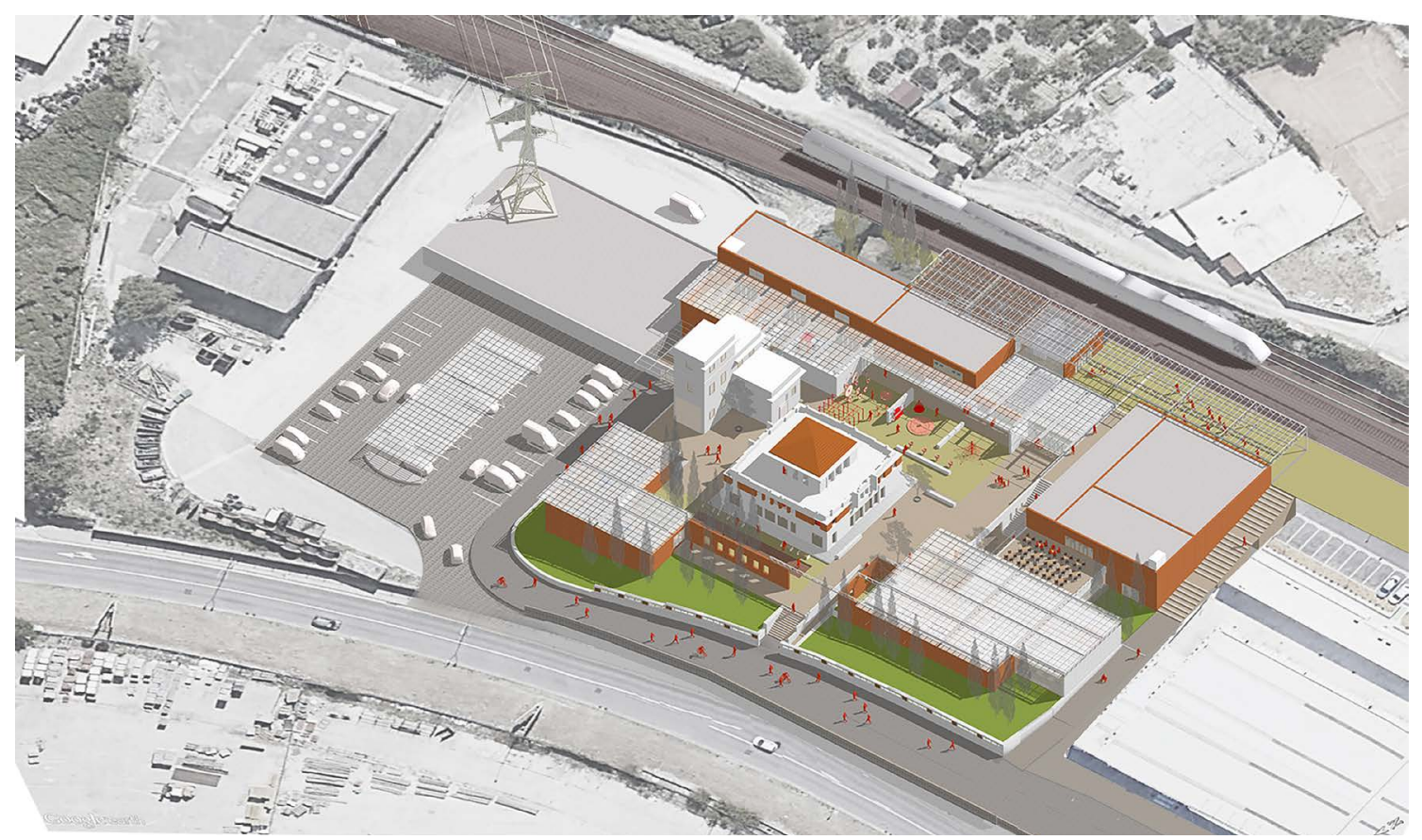

Figure 19. An isometric projection of Kodl's substations in the center and the volumes of the planned Science Center. Kodl's main substation is located centrally (with a red roof), while the railway station and track are visible on the northern part as an integrated part of the Science Center building. The upper left corner shows the contemporary electrical substation that is currently in function (shown in greyscale).

\section{Integrating the volume with the context}

The formal approach considers how the functional, conceptual, contextual, and material elements of design manifest in the shape of the building. One must take into account conservation guidelines that concern, for example, the height of the cornice, the distance from Kodl's substations, the choice of materials and colors, as well as the general treatment of existing buildings. In this case, the forms of spatial volumes follow the "objective" design principle, with the aim of optimally meeting the functional requirements while reducing consumption.

The volume is deconstructed into smaller units that can be better incorporated into the existing tissue to create a milder or more unobtrusive relationship with Kodl's buildings. The height of the volumes is visually reduced by pushing the two-story volumes into the background, while the eaves or porches bring everything down to a human scale and create a greater sense of a humanistic pavilion exhibition. The crux of urban and architectural design in general is primarily in integrating the new with the existing elements or modifying and adapting the existing elements to the new conditions, without alienating them from the "original" context. In contrast, the no-commitment design yields arbitrarily variable results that are disconnected from their environment (Prinz, 2008) (see Figure 19). 
According to the Gestalt psychology of visual perception, if form is expressive, shape and volume take precedence, while matter is mostly unexpressed (Šerman, 2015a). In painting, strong forms and contours weaken the presence of color and matter; similarly, colorists use Gestalt to maximize the interaction between colors (Pallasmaa, 2000; Šerman, 2015a). The relationship with Kodl's architecture therefore manifests as a relationship between the central pavilion (the core of the whole) and the modular structure of walls without an articulated shape or volume. In this way, Kodl's substation is allowed to stand out owning to its plasticity, tangibility, and different materials (Figure 19). The purpose of interior rectangular forms is to meet the functional and design requirements in an optimal way; however, they also serve an aesthetic function by maintaining the continuum of structural and design features. The capacity for modular expansion of the structure and its flexibility is a notable advantage for the future development of the Science Center and by allowing the possibility of modifying its contents.

The height of the walls has been adapted to the cornice of Kodl's substation to emphasize its roof (Figure 20). In this case, the position and proportions of openings and the use of architectural accents in the material and details at the joints serve as a "subjective" design principle, as well as the bearer of meaning (Prinz, 2008).

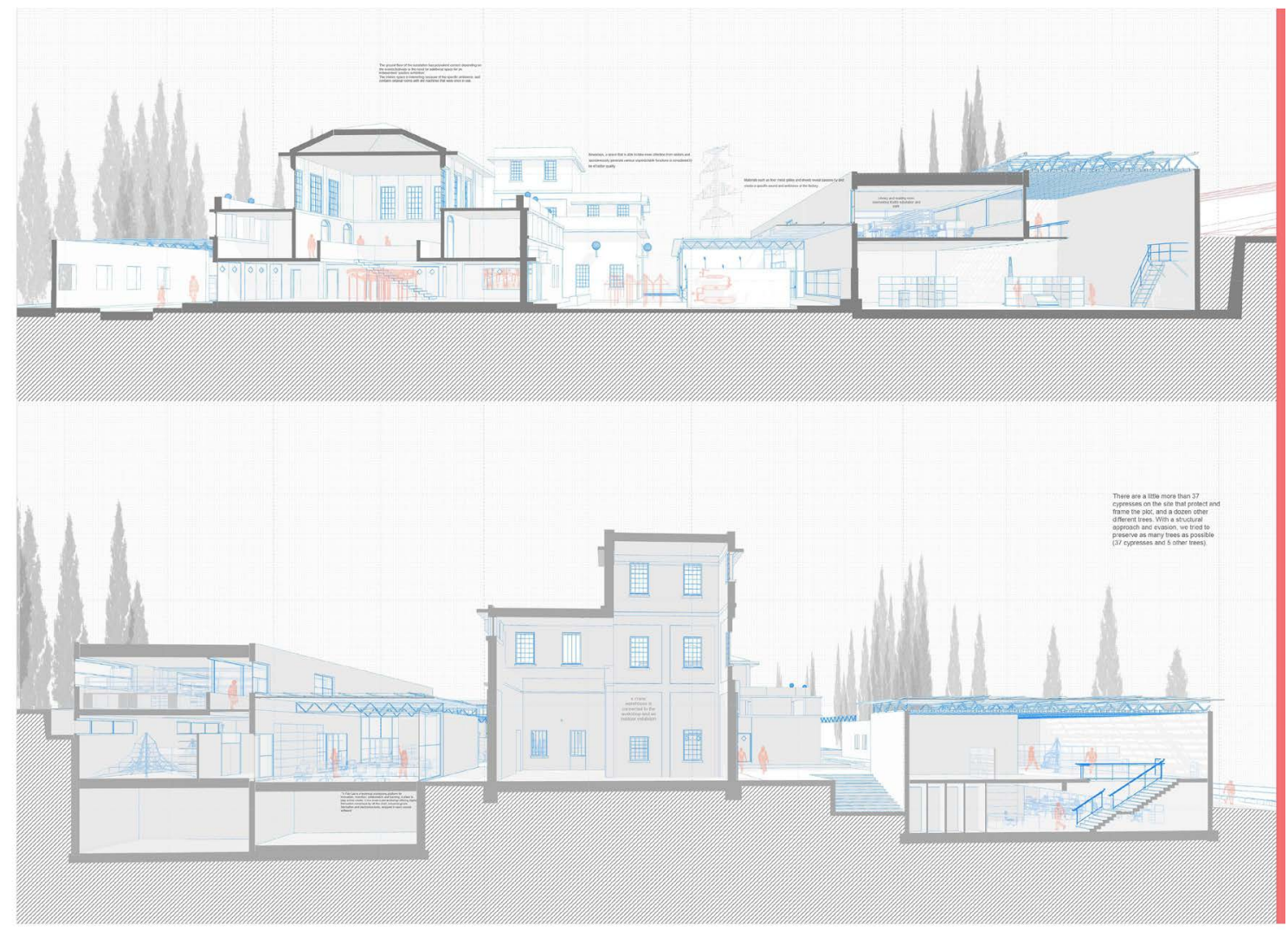

Figure 20. Sections through Kodl's main and auxiliary substation in a north-south direction. The height of the walls has been adapted to the cornice of Kodl's substation to emphasize its roof. The ground floor of Kodl's substation and the open space between it and the planned buildings contain polyvalent content that changes depending on the current events, festivals or the need for additional space. 


\section{Results: a description of the proposed solution}

As a result of detailed planning and conceptual exploration described above, what is described here is an overall outline of what this means for the proposed plan of the Science Center. The Center is conceived as a hybrid between a science institute and a socio-cultural center that combines the following: a science and industry museum, several types of workshops for various purposes, a polyvalent hall, and a scientific research institute. In this project, Kodl's main substation plays a central role in the Science Center and showcases the soft values of industrial heritage revitalization. The main and auxiliary substations are envisaged as pavilions of "future technology" for the testing and verifying of state-ofthe-art technologies, and the auxiliary substation may also be linked to workshops.

The content of the multipurpose ground floor of the main substation may be adapted to different events or festivals (Figure 21). The original space of the substation is interesting due to its characteristic ambiance and original rooms that still house their once-operational machines. The gallery $\left(200 \mathrm{~m}^{2}\right)$ around the illuminated atrium on the first floor of Kodl's main substation can host an interactive exhibition of new technologies and innovations. There are stairs leading from the atrium to the substation terrace, which can also be used as a place to rest, socialize and observe.

The Science Center can be accessed by vehicles from the Solin-bound road (Solinska cesta) on the north side of the land parcel. Pedestrian and disabled access is to be provided from the north, where pieces of Kodl's original entrance have been preserved (Figure 21).

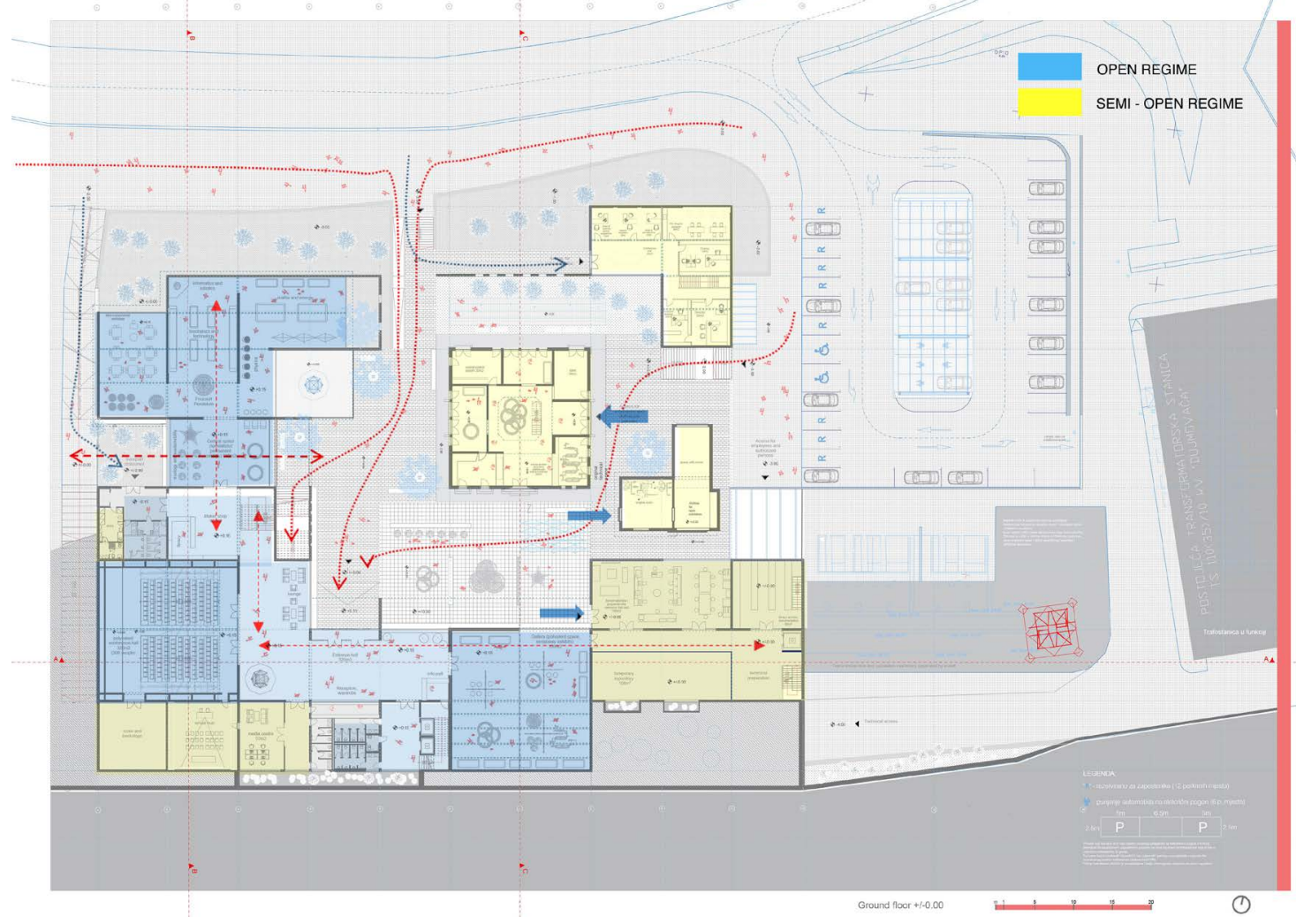

Figure 21. The ground floor plan of the Science Center at the level of the inner courtyard. Red arrows indicate the directions of movement within and main access to the Science Center complex. Blue arrows indicate the other entrances and separate access points for the semi-open regime. 
The entrance hall of the Center is cater-cornered to Kodl's main substation. The ground floor of the entrance hall connects the two wings of the building, integrates the interior with the courtyard, and provides independence and separate access to the gallery (the temporary exhibition) and the permanent exhibition. It balances and connects the two sides of the volume of the Science Center (Figure 21).

The park, i.e., the inner courtyard of the Center with Kodl's two buildings, would remain open to the Center's visitors, railway passengers, and passers-by who wish to visit the park, open-air exhibition, restaurant, or café. The museum space may thus be divided into an outdoor museum space that does not require an entrance fee and a controlled indoor museum space that requires a fee. Visitors enter through the main, representative museum entrance (Figure 21). After passing the reception facilities - the front desk, box office, and cloakroom - visitors may tour the museum and current exhibitions, visit the library, attend a lecture, or just sit in the café or restaurant. Temporary exhibition spaces are clearly set apart from permanent exhibitions. These spaces are connected to two different access areas for ease of delivery, in order to provide a safe, sufficiently wide, and accessible pathway for museum exhibits.

The planned location of the parking lot is east of the Science Center, on what is currently the outdoor disposal site of the electrical substation (Figure 22). Wires, poles, and other useful materials from the outdoor disposal site will be moved to an empty and neglected area to the east of the new substation. This newly-freed space will be turned into a common parking lot for visitors and staff of the Center and the substation in use. It should include 50 car parking spots and two bus bays. The substation in use and its access are clearly separated.

The Science Center may also be accessed from the parking lot through a separate staff, delivery, and fire engine entrance. The administration building will also have a separate staff entrance. The entrance area on the parking lot floor has an entrance hall that holds toilets and a changing room and is connected to the media center, conference hall, nine offices, and a kitchen (Figure 22).

The workshops are connected to storage rooms and a photo lab in the closed access area, as well as with exhibition spaces in the open access area. This part of the museum also holds the library storage and documentation archive. Workshops and laboratories can also be accessed directly from the parking lot for staff and students (Figure 22). There is also an optional separate visitor access to workshops and the pavilion exhibition in Kodl's substation that connects to the park and outdoor exhibition. Workshops for children are next to the permanent exhibition space and are visually connected to the restaurant and the playground (see Figure 21).

Exhibits from other museums featured in temporary exhibitions have to go through unpacking and package disposal spaces, and, if need be, the repair workshop, before arriving at the temporary exhibition space. Specialized indoor vehicles may also be used to transfer larger items. The storage, restoration, and preparation space for museum pieces provides a link between the closed and semi-open access area. Exhibits can be safely and securely moved between these spaces to the exhibition space in the open access area. 


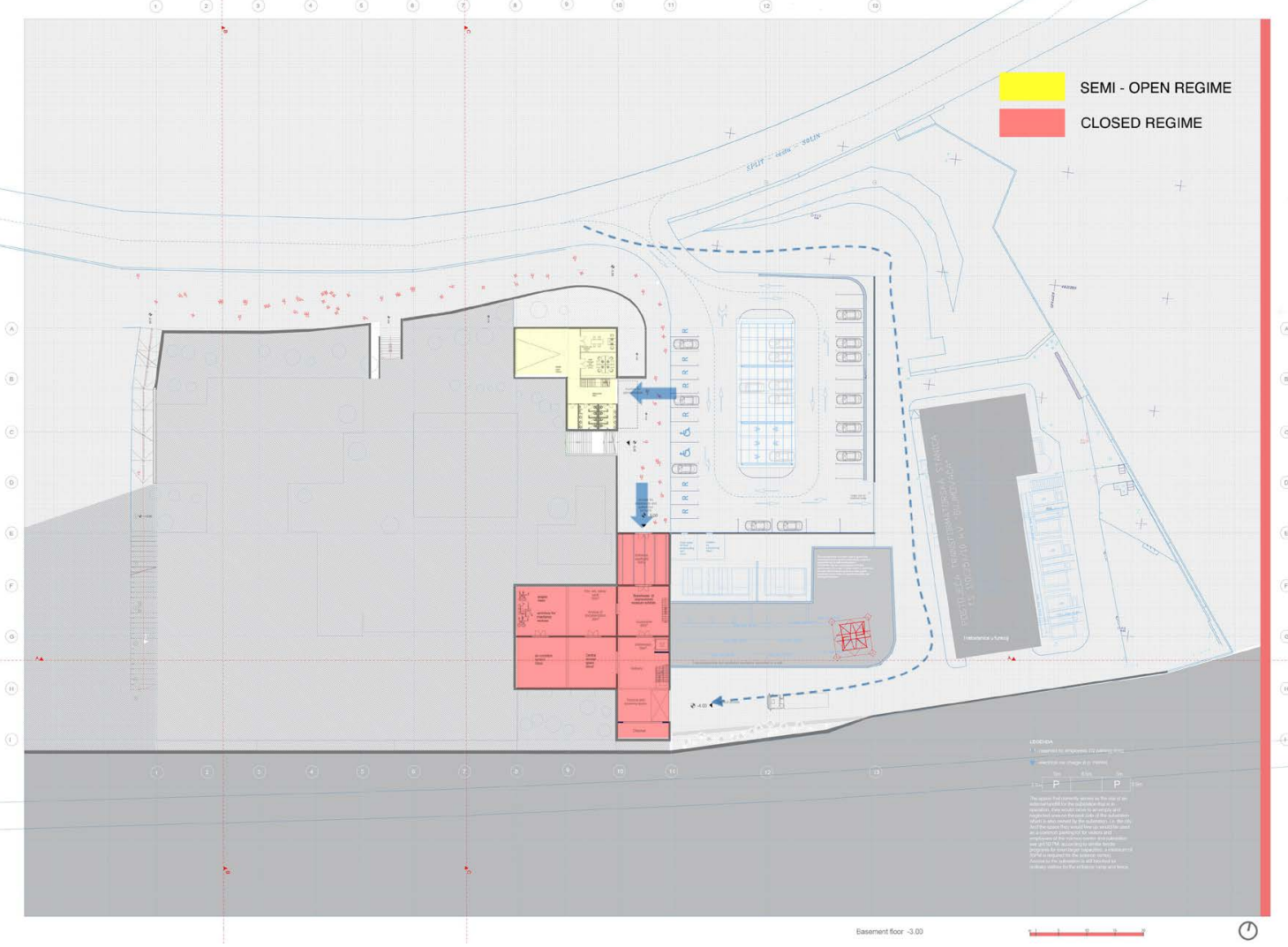

Figure 22. The ground plan of the basement of the Science Center at the parking lot level. Blue arrows indicate the entrances to the building.

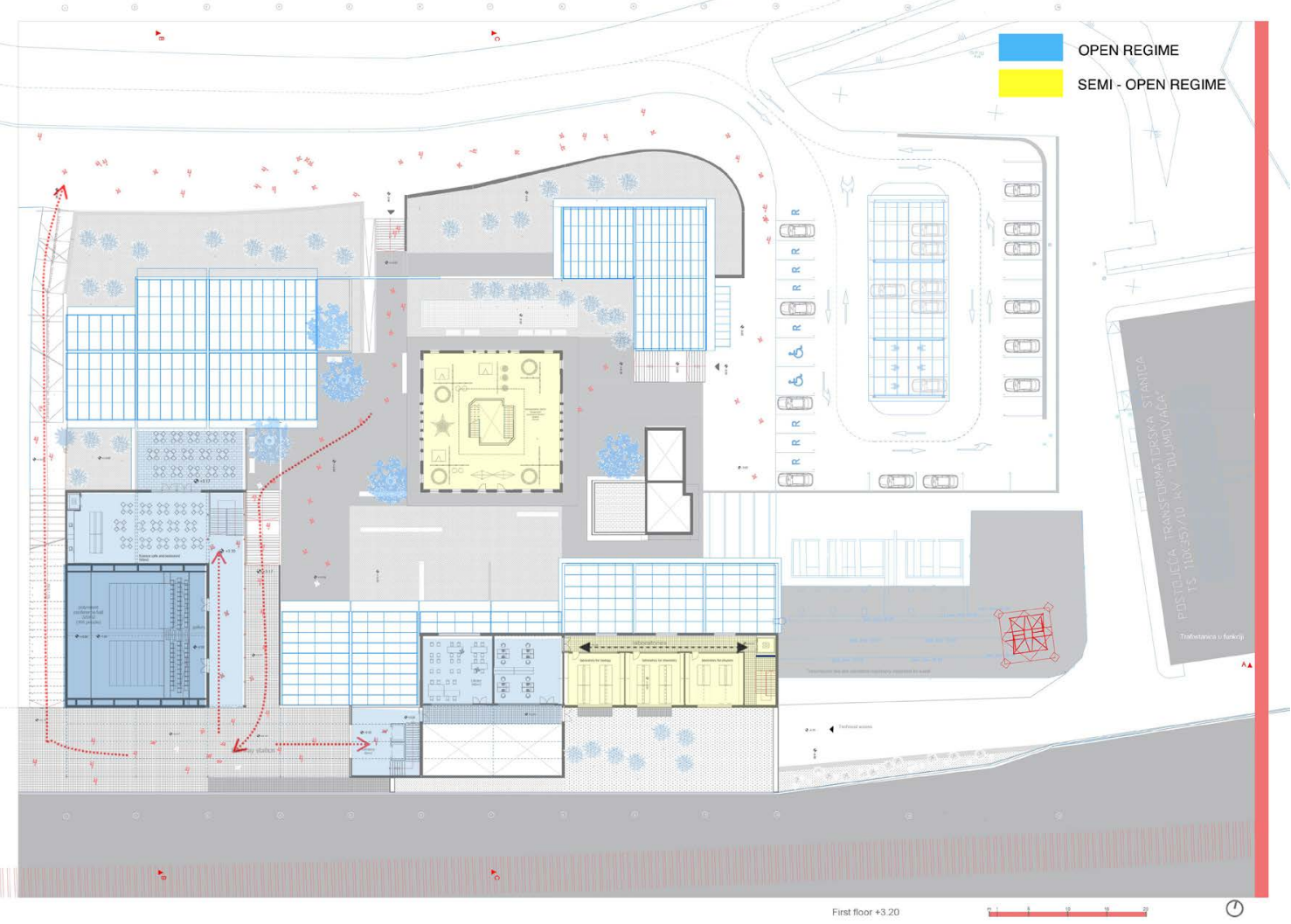

Figure 23. The ground plan of the 1st floor of the Science Center at the railway level. Red arrows indicate the directions of movement within and access to the Science Center complex. 
Vans, fire engines, and staff may access the Center from the west. This access route also connects the railway station with the northern pedestrian street, and may potentially connect to the Science Center in the second stage of expansion. To the south of the project, a railway station connects the Science Center with the city center and, potentially, with the Split Airport (Figure 23).

On the first floor, the railway station is connected to the entrance hall through a covered passageway, and there is also an independent open staircase connecting the railway station to the park. In addition to the main access through the entrance hall, a separate access point exists to enable independent operation of the polyvalent hall and restaurant. In the other wing, the library, reading room, and labs may be accessed through a dedicated entrance (Figure 23; Appendix 5).

The substation is a part of the central inner courtyard, but it also divides the courtyard into smaller sub-units. Instead of a large hall, the space for exhibits and visitors is within the structure of various sceneries or micro-ambiences linked to the park and the outdoor exhibition. This seemingly erases the boundary between open and closed spaces and opens up the exhibition spaces (Figure 24). Visitors are encouraged to participate in an exhibition by choosing an arranged path or a learning program. Along with this, they also observe the reactions of other visitors; thus they are invested in the development and interpretation of events around them (Appendix 6). A video tour of the Science Center complex is available in Appendix 7.

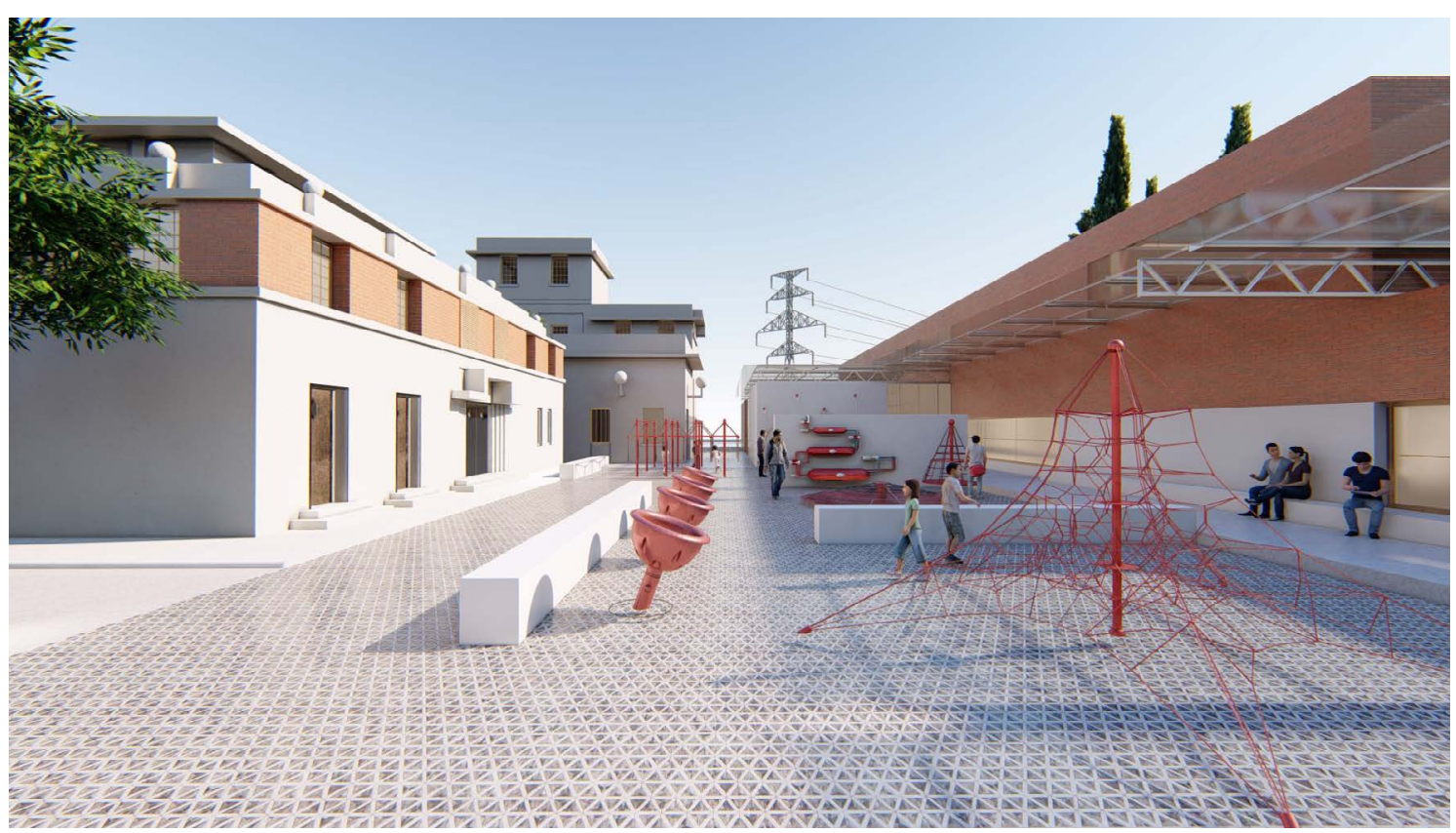

Figure 24. Visualization of the outdoor exhibition opposite the main entrance to the substation. Red objects indicate the temporary exhibits depending on the current event, festival or fair. 
After the schematic design phase is complete, this proposal calls for consultations with different professions involved in the actual realization of the building, where one can expect certain adaptation and interdisciplinary cooperation to be necessary. Overall, all the complex infrastructure that is necessary for the functioning and exhibition needs of the Center will likely have an effect on the architecture and the way the space itself would be experienced. Therefore, the idea behind this design is to present and reveal the infrastructure and various controlled automated systems, such as lighting systems, heating, air conditioning, and ventilation, alongside the scientific showpieces and their installations, as part of an industrial and demystifying design (Figure 24). An example of and reference for a similar separation of the infrastructure from the walls and architecture is the Pompidou Center in Paris, designed by architects Renzo Piano and Richard Rogers and built in 1977 (Dezeen, 2019).

The building itself should thus be a kind of "showroom" for technology by employing, for example, sustainable construction such as solar cells/panels. Additionally, cooperation with corporations could be consistently fostered through temporary exhibitions or interactive content in the outdoor part of the museum (courtyard or square) (aFRONT Spatial Innovation Institute, 2018). By creating value for technology giants, as well as small businesses, the science and research center may achieve a stable financial footing, which would contribute to its control over its content. The cooperation and close relationship with corporations and innovators are crucial to ensuring the continuous development and progress of this project.

Table 2 shows potential topics for permanent and temporary exhibitions and contents of the Science Center. Table 3 shows the spatial parameters of the Science Center, while detailed measurements for its planned contents are listed in appendices (Appendix 8).

Table 2. Potential topics for exhibitions and programs in the Science Center

Sea: seamanship, shipbuilding, navigation, oceanography, mariculture, etc.

Energy: green energy, gas, wind, sun, and other energy sources

Health: medicine, pharmacy, and chemistry

Environmentalism: environmental protection, organic farming

Building: architecture, civil engineering, and transport

Information technology: computing and telecommunications

The industrial history of Split

Table 3. Quantitative parameters of the Science Center

Parcel area:

Floor-Area Ratio (FAR)

Building Coverage Ratio (BCR)

The area of Kodl's buildings

Gross Building Area (GBA)

Road and pedestrian access approx. $14,200 \mathrm{~m}^{2}$

$6,622 \mathrm{~m}^{2} / 14,200 \mathrm{~m}^{2}=0.47$

$4056 \mathrm{~m}^{2} / 14,200 \mathrm{~m}^{2}=0.29$

$322 m^{2}+130 m^{2}=452 m^{2}$

$3604 m^{2}+452 m^{2}=4056 m^{2}$

From the Solin-bound road (Solinska cesta) 


\section{An analysis of the proposed solution}

The proposed solution is a hybrid of a science institute and a socio-cultural center. This conceptualization of space seeks to create a sense of belonging and a balanced attitude to the context and needs of the city. As a scientific and cultural institution and an unconventional place, it calls for an innovative and technologically advanced design to enable the installation of state-of-the-art technologies and systems and must continue to evolve over its long lifespan.

\section{Strengths and limitations of the featured content given the chosen location}

One of the limitations of this project is the size of the land allotment. The solution to this issue was to try and optimize the program of the Science Center towards specific topics that are suitable to its size and its phased construction. This is why the architectural design process simultaneously examines the limits and the potential of the location but also considers the wider cultural context of the location, as well as its temporal development; "it is thus not a product of a single decision or an arbitrary architectural design" (Prinz, 2008). This also allows for the possibility of adaptation and fosters an "openness" of the system over the course of its development (see Sennett, 2016), representing a transfer of the control over the architectural design to a team of engineers, contractors, manufacturers, politicians, and experts in technology and other disciplines that are relevant to the running of a science center and its content.

According to the Bigness theory of Rem Koolhaas, it is impossible to animate an entire mass with intention when working with architecture of a large scale and high complexity (see Koolhaas, 1995). The complexity of content in this project liberates the function of the building from the limitations of its predetermined program and fosters the creation of new events. In modern times, characterized by the emergence of new technologies and rapid exchange of information, precedence is given to spaces that are capable of both attracting the attention of visitors and spontaneously generating a variety of unpredictable functions (Homadovski, 2018).

The location inspires a hybrid architecture typology, which is both its limitation and its advantage, as the Center needs to function both as a museum and a science and research institute, while also functioning as a railway station.

\section{A theoretical and practical analysis of the architectural design method}

Under the modernist principle that dictates that form follows function, a building is comparable to a machine (Fisher, 2016; Šerman, 2015b). This is particularly relevant from today's perspective, where any building featuring "smart" technologies, complex infrastructure, and strict rules turns into an increasingly complex project that requires the involvement and synergy of several professions (Turato, 2018). However, the fundamental difference in the architectural design of a building in comparison with the functionalist design of a machine is that architecture, in addition to the relationship between form and function, also addresses the relationship between the external and internal space as well as the space between them - the semi-public, semi-private "in-between-space" (see 
Hertzberger, 2008). The proposed solution for the Science Center and its design concept focuses on the relationship between the external and internal space and designing its visible and invisible boundaries. Its scale is adapted to humans, embraces ambivalence, and raises the question of whether it is perceived as a public or private, introverted or extroverted space (see Figure 16).

It was this concept that determined the choice of zenithal lighting and the articulation of technical details due to the layered composition of the walls and the floor plan depth (see Figure 15). In the words of Alvaro Siza: "A project is to an architect what a character in a novel is to a writer; it constantly eludes them. It must never be lost” (Siza, 2006). This architectural concept, by focusing on the relationship between the external and the internal, by actually defining their visible and invisible boundaries, provides a framework for decision-making for the entire project and affects many of its aspects, generating and intertwining with details added to its design.

The limitation of such a conceptual approach is that architecture, in a project of this scale, can become too dependent on the articulation and intellectual power of the concept and the clarity of its application in the design. As Juhani Pallasmaa says in his essay on materialization and tactility in architecture, this places too much emphasis on the conceptualization of an idea and bringing its implementation to perfection, which can detach an architectural object from the reality of its time and use (Pallasmaa, 2000). Following the design principle of the opera aperta, the open form, the author strived to introduce the kind of approach that fosters the development of alternative associations and the elaboration of details. Additionally, the project opens up in situ opportunities for experimentation and improvisation at the site itself (Pallasmaa, 2000).

\section{The relevance of this work and its impact on potential new studies}

The proposed solution could be realized through the development of the northern coast of the city of Split and renew the interest in the work of Split architect Josip Kodl and the industrial heritage of the city. It enriches the narrative and identity of the city and implies a step towards the future through the promotion of new technologies and by creating a regional innovation hub. The focus is not only on the result or the envisioned building and its program but also on the design process itself. Using a stepwise approach, the proposed solution was adapted to its location, historical context, and conservation heritage. Finally, the proposed solution is not just the result of an arbitrary association of fragments but rather functions within a whole, as part of a larger urban morphology.

Crossing the boundaries between different disciplines is necessary to find new, effective answers to complex urban challenges. A holistic scientific approach includes taking political, socioeconomic, and aesthetic practices into account, accepting and embracing complexity as a matter of principle (Mehaffy \& Salingaros, 2012). The complexity of the proposed solution stems from the organization and integration of opposed elements in spite of their differences. The proposal integrates the flow of railway passengers and the interactivity provided to the visitors of the Science Center, combines scientific congresses/research with cultural/art events, integrates development/revitalization elements with conservation/conversion efforts, and, finally, by uniting a park-based architectural design 
with the industrial/historical context of the location. Elements designed as a result of this integrative approach have much deeper links within the system as a whole, which the quantum physicist David Bohm has called “implied connections” (Kožnjak, 2010).

The Science Center is designed to integrate into Split's urban network through multiple layers of context, in order to avoid being an isolated fragment within a whole. Through this, it achieves its full potential, making the most of the resources and opportunities of its location and context provide. This integration also allows it to function as a unified, authentic whole. In other words, this building is wholly unique to its location and could not exist anywhere else.

\section{Conclusion}

Given the wide scope of what has been discussed, including the work of the Science Center, its urban and strategic impact on the northern coast of the Split peninsula, and the restoration and protection of Kodl's legacy, it can be concluded that the purpose of this report was to expand the interest for the potential of this part of Split and understand its advantages and disadvantages.

Located in the industrial zone and forming one of the first impressions for entering the City of Split by rail, the proposed Science Center is situated in a remarkable strategic position that connects the fragmented urban tissue and includes diverse, ambivalent features, which in turn foster hybridity, development, and contemplation. The positioning of the Science Center would form a link between the University of Split and developing information technology industry, which is complementary to the success in tourism industry.

This work seeks to preserve, repurpose, and spotlight the neglected architectural work of Josip Kodl as one of the first modern buildings in Croatia and in Europe. In keeping with conservation guidelines, a more open and moderate attitude has been fostered toward Kodl's substation and its auxiliary building, which are seen as an independent nucleus within a larger system, allowing them to function independently of the rest of the Science Center.

The proposed Science Center solution and its design concept focus on the relationship between the external and internal space of the building and pose the question of whether a given space is to be perceived as public or private, introverted or extroverted. From the viewpoint of contemporary culture and modern media, space has been given a new context for evaluation and potential new values that have thus far been neglected or have gone unnoticed.

The architectural design process simultaneously examines the limits and the potential of a location; it is not a product of a single decision or an arbitrary architectural decree, but an extension of the wider culture of a place and its temporal development. The structure and aesthetics of the building complex provide opportunities for its modular expansion in later stages of development of the Science Center, as well as a framework for implementing current and future content and functions. It takes time for architecture of this nature and scale to be accepted and loved by the community, to become a ritual for the citizens, and, ultimately, an integral part of the city. 
Provenance: Submitted. This manuscript is based on the master's thesis by Sandro Žuljević at the University of Split, Faculty of Civil Engineering, Architecture and Geodesy, and deposited in the Dabar repository (https://urn.nsk.hr/urn:nbn:hr:123:593628).

Peer review: Externally peer reviewed.

Received: 14 April 2021 / Accepted: 21 October 2021 / Published online: 23 December 2021.

Funding: This research received no specific grant from any funding agency in public, commercial or not-for-profit sectors.

Acknowledgements: I would like to express my gratitude to my mentor Ante Kuzmanić and co-mentor Hrvoje Bartulović for their advice and dedication during the writing of my thesis. I also wish to thank the members of the thesis defense committee Nikola Popić, Dinko Peračić, and Dujmo Žižić, for contributing to the thesis with their useful comments. I am grateful to Petra Ivanišević for her help in providing materials and photographs of the location. I especially wish to thank Marija Franka Žuljević for her great help and support.

Authorship declaration: SŽ is the sole author of this study.

Competing interests: The author completed the ICMJE Unified Competing Interest form (available upon request from the corresponding author), and declares no conflicts of interest in relation to the work presented in the article.

Additional material: This article contains electronic supplementary material which is available for download at st-open.unist.hr.

\section{ORCID}

Sandro Žuljević (D) https://orcid.org/0000-0002-7992-530X

\section{References}

aFRONT Spatial Innovation Institute. (2018). International, open, one stage design competition for selecting the most professionally appropriate solution for: Science centre.

Ahac, M., Lakušić, S., Ivančev, M., \& Čudina, A. (2017). Idejno rješenje željezničke pruge Split-Trogir. Željeznice, 16(2), 7-15.

ArchDaily. (2011). AD Classics: Menil Collection / Renzo Piano. Retrieved from https://www.archdaily. com/171974/ad-classics-menil-collection-renzo-piano.

Arhitektonska radionica centar d.o.o. (2015). Science museum initiative. Retrieved from https:// www.arc-st.hr/initiative.

City of Split. (2007). Izmjene i dopune generalnog urbanističkog plana Splita. Službeni Glasnik Grada Splita No. 1/06, 15/07, 3/08, 3/12, 32/13, 52/13, 41/14, 55/14 - Consolidated Text, Council of the City of Split. Retrieved from https://www.split.hr/DesktopModules/Bring2mind/DMX/API/Entries/ Download?language=hr-HR\&Command=Core_Download\&EntryId=3170\&PortalId=0.

City of Split. (2015a). Generalni urbanistički plan Splita. Službeni Glasnik Grada Splita, No. 1-06, Council of the City of Split, Article 23. Retrieved from https://www.split.hr/ DesktopModules/Bring2mind/DMX/API/Entries/Download?language=hr-HR\&Command=Core Download\&EntryId=3181\&PortalId=0.

City of Split. (2015b). Strategija kulturnoga razvitka grada Splita 2015.-2025. Službeni Glasnik Grada Splita, No. 50. Retrieved from https://www.split.hr/DesktopModules/Bring2mind/DMX/API/ Entries/Download?language=hr-HR\&Command=Core_Download\&EntryId=5054\&PortalId=0.

Croatian Democratic Union. (2013). Split kakav želim. Split, Croatia: Redak.

Dezeen. (2019). Centre Pompidou is high-tech architecture's inside-out landmark. Retrieved from https://www.dezeen.com/2019/11/05/centre-pompidou-piano-rogers-high-tech-architecture. 
Duplančić, V. (2004). Obalni pojas grada Splita u urbanističkim planovima, projektima i studijama u razdoblju od 1914. do 1941. godine. Prostor, 12(1(27)), 111-120.

Fisher, S. (2016). Philosophy of Architecture (Supplement), The (Stanford) Encyclopedia of Philosophy (Winter 2016). Metaphysics Research Lab, Stanford University. Retrieved from https://plato.stanford.edu/entries/architecture/tradition.html?utm_medium=website\&utm_ source=archdaily.com.

Fondation Beyeler. (2021). In Harmony with Nature and Art. Retrieved from https://www. fondationbeyeler.ch/en/museum/architecture-and-nature.

Hafner, A. (2002). Piano, piano do Muzeja savremene umjetnosti, ARS AEVI, Sarajevo. Informatica Museologica, 33(3-4), 64-66.

Hertzberger, H. (2008). Space and Learning: Lessons in Architecture 3. Rotterdam, Netherlands: 010 Publishers.

Homadovski, A. (2009). Transformacije institucija kulture - Suvremene muzejske destinacije i utjecaji vrijednosti industrijskog brandinga. Prostor, 17 (2(38)), 386-394.

Homadovski, A. (2018). Architectural Programs as Corporate Communications Platforms. Prostor, 26(1(55)), 82-93. doi: https://doi.org/10.31522/p.26.1(55).6.

ICCROM, ICOMOS, IUCN, \& UNESCO. (2013). Managing Cultural World Heritage. Paris, France: The United Nations Educational, Scientific and Cultural Organization.

Ifko, S. (2017). Protection of Authenticity and Integrity of Industrial Heritage Sites in Reuse Projects. In S. Ifko \& M. Stokin (Eds.), Protection and Reuse of Industrial Heritage: Dilemmas, Problems, Examples (pp. 45-57). Ljubljana, Slovenia: ICOMOS Slovenia.

Institut IGH d.d. (2011). Prostorno-prometna studija šireg područja grada Splita (knjiga I). Retrieved from https://es.split.hr/Documents/2018/08/23/Knjiga 1.pdf.

Ivanišević, V. (2010). Elaborat o osnivanju muzeja znanosti u Splitu (unpublished).

Janson, A., \& Tigges, F. (2013). Fundamental Concepts of Architecture: The Vocabulary of Spatial Situations. Basel, Switzerland: Birkhäuser Verlag.

Klempić, S. (2004). Razvoj stambenih naselja Splita nakon Drugog svjetskog rata. Hrvatski Geografski Glasnik, 66(2), 95-119.

Koolhaas, R. (1995). Bigness or the problem of Large (Small, Medium, Large, Extra-Large) (pp. 9-10). Monacelli Press. Retrieved from https://politicshyperwall.files.wordpress.com/2017/10/ koolhaas-rem-bigness-1994.pdf.

Kožnjak, B. (2010). David Bohm, Cjelovitost i implicitni red. Prolegomena, 9(2), 337-351.

Maroević, I. (2002). Elementi za projektni program izgradnje muzeja. Informatica Museologica, 33(34), 67-73.

Mehaffy, M., \& Salingaros, N. A. (2012). Science for designers: The meaning of complexity. Retrieved from https://www.metropolismag.com/uncategorized/science-for-designers-the -meaning-of-complexity/?utm_medium = website\&utm_source=archdaily. com\&fbclid=IwAR1ppQSPjUtndSw819fkYMLsoV3lIh_PxpvLD8zZeel5XwlXMpidq_f-N6E.

Minghang, D., \& Guanghu, J. (2021). Analysis on the Protection and Reuse of Urban Industrial Architecture Heritage. IOP Conference Series: Earth and Environmental Science, 787(1), 012175. doi: 10.1088/1755-1315/787/1/012175.

Ministry of Culture of the Republic of Croatia. (2012). Izvod iz Registra kulturnih dobara Republike Hrvatske No. 03/2012: Lista zaštićenih kulturnih dobara (NN 120/2012). Retrieved from https:// narodne-novine.nn.hr/clanci/sluzbeni/2012_10_120_2611.html.

Mollard, M. (2016). A museum's architecture shouldn’t be its best exhibit, but at the Tate Modern it steals the show. Retrieved from https://www.architectural-review.com/buildings/a-museumsarchitecture-shouldnt-be-its-best-exhibit-but-at-the-tate-modern-it-steals-the-show.

Muljačić, S. (2005). Crkvica sv. Duje u Dujmovači i kapelica na Kmanu. Kulturna Baština, 32, 271-284.

Museum Planner. (2013). Science Centers Leading the Way. Retrieved from https://www. museumplanner.org/science-centers-leading-the-way.

Nikolić, G. (2017). Industrija i obrazovanje. Andragološki Glasnik, 21(1-2 (36)), 37-48.

Pallasmaa, J. (2000). Hapticity and Time: Notes on fragile architecture. Retrieved from https://www. scribd.com/document/215195770/Hapticity-and-Time. 
Palmer, M. (2008). Industrial archaeology. In D. M. Pearsall (Ed.), Encyclopedia of archaeology (pp. 1496-1506). New York, NY: Academic Press.

Pavičić, J. (2016). Mediteran: Soba bez pogleda. In Knjiga o jugu (pp. 7-25). Zagreb, Croatia: Profil Knjiga.

Pickard, R. (2017). The Council of Europe and the Industrial Heritage: A UK exemplar of the rehabilitated industrial heritage as a resource for society. In S. Ifko \& M. Stokin (Eds.), Protection and Reuse of Industrial Heritage: Dilemmas, Problems, Examples. Ljubljana: Slovenian National Committee of ICOMOS /International Council on Monuments and Sites/.

Piplović, S. (1987). Splitski arhitekti Š. Nakić i J. Kodl: Od eklekticizma do moderne. Kulturna Baština, 17, 88-104.

Piplović, S., \& Franić, B. (2003). Hrvatski biografski leksikon:Josip Kodl. Zagreb, Croatia: Leksikografski zavod Miroslav Krleža. Retrieved from https://hbl.lzmk.hr/clanak.aspx?id=9623.

Plejić, R. (2003). Utjecaj praške škole na arhitekturu moderne u Splitu (doctoral dissertation). Arhitektonski fakultet u Zagrebu.

Preziosi, D. (1983). Minoan Architectural Design: Formation and Signification. The Hague, Netherlands: De Gruyter Mouton.

Prinz, D. (2008). Urbanizam: Svezak 2. - Urbanističko oblikovanje (Croatian edition based on the 1997 sixth German edition). Zagreb, Hrvatska: Golden marketing - Tehnička knjiga.

Sennett, R. (2016). The Open City (essay). Retrieved from https://newformalism.aaschool.ac.uk/wpcontent/uploads/2019/02/The-Open-City.pdf.

Siza, A. (2006). Zapisi o arhitekturi (Scritti di architettura). Zagreb, Croatia: Biblioteka Plan.

Split Portal. (2013). Splitska podzemna željeznica. Retrieved from http://split.com.hr/novosti/vijesti/ splitska-podzemna-zeljeznica.

Swiss Science Center Technorama. (2021). About Us. Retrieved from https://www.technorama.ch/en/ about-us.

Šerman, K. (2015a). Teorija arhitekture akad. godina 2002./2003., Priručnik za praćenje nastave. Fakultet građevinarstva, arhitekture i geodezije u Splitu.

Šerman, K. (2015b). Teorija arhitekture I, Priručnik za praćenje nastave. Arhitektonski fakultet u Zagrebu.

Šulc, B. (1989). Muzeji potkraj 20. stoljeća: Nove osnovne muzejske orjentacije u evropskim i izvanevropskim zemljama u prezentaciji. Informatica Museologica, 20(1-2), 8-13.

Turato, I. (2018). Arhitektura instalacija - instalacija arhitekture. Retrieved from https://www. idisturato.com/blog/2018/02/11/arhitektura-instalacija-instalacija-arhitekture.

Uchytil, A., Barišić Marelić, Z., \& Kahrović, E. (2009). Leksikon arhitekata Atlasa hrvatske arhitekture. Arhitektonski fakultet u Zagrebu.

UNESCO. (2021). Zollverein Coal Mine Industrial Complex in Essen. Retrieved from: https://whc. unesco.org/en/list/975/.

van der Kemp, R. (2009). Value and revitalizing industrial heritage (master thesis), Technical University of Eindhoven, Eindhoven.

Žižić, D. (2015). Povijest industrije cementa u Dalmaciji: 150 godina suživota (doctoral dissertation). Fakultet građevinarstva, arhitekture i geodezije u Splitu. 